\title{
Çıkar ve Güç Dengesi Kıskacındaki Ahıska Türkleri Sorunu ${ }^{(*)}$
}

\section{The Issue of Ahıska Turks in The Clamp of The Balance of Power And Interest}

\author{
Mustafa ÜREN ${ }^{(* *)}$
}

\section{Özet}

Ahıska Türkleri Sorunu, Ahıskalıların 14 Kasım 1944'deki sürgünüyle başlamış olsa da, kökleri çok daha eskiye dayanmaktadır. Sorunun Rus çıkarlarıyla bağlantısı, çözümsüzlüğ̈̈nün en önemli nedenlerinden birini oluşturmaktadır. Ahıskalılar, 1956 yılında başlattıkları geri dönüş mücadelesinden henüz bir sonuç alamamışlardır. Sovyetler Birliği'nin dă̆ılmasılla sorun, uluslararası bir nitelik kazanmıştır. Gürcistan, Ahıska Türklerinin geri dönüşüne karşıdır. Ancak 1999 yılında Avrupa Konseyi ne üye olma şartı gereği, Ahıska Türklerinin geri dönüşünü kabul etmekzorunda kalmıştır. Buna göre geri dönüs sürecini 2011 yılında tamamlaması gereken Gürcistan, 11 Temmuz 2007'de geri dönüs yasasını onaylamasına ră̆men, süreci kasten sürüncemede bırakma eğilimindedir. Sorunun taraflarl; başta Ahıska Türkleri olmak üzere Gürcistan, RF ve Türkiye'dir. Tarafların soruna yönelik politikalarını belirlemede çıkarları etkili olmaktadır. Bununla birlikte Ahıskalıların kimlikleri ile Ahıska'nın jeostratejik konumu, söz konusu politikayl şekillendiren diğer iki önemli faktördür. Bu faktörler, Ahıskalıların sürgün kararında etkili olduğu gibi, Rus çıkarlarıyla ilişkisini sağlayan asıl etkenlerdir. Bunların yanında, Soğuk Savaş sonrasında Kafkasya'da oluşan güç dengesi de, sorunun çözümünü olumsuz yönde

(*) Çalışmada AİBÜ Sosyal Bilimler Enstitüsü tarafından onaylanan "Kimlik, Çıkar ve Jeopolitik Ekseninde Ahıska Türkleri Sorunu" isimli tezden istifade edilmiştir,

(**) Dr., doktora eğitimini, AİBÜ Sosyal Bilimler Enstitüsü Uluslararası İlişkiler Anabilim Dalında tamamlamıştır. E-mail: mustafauren4410@yahoo.com 


\section{Mustafa ÜREN}

etkilemektedir. Sorunun Rus çıkarlarıyla bağlantısından dolayı, bölgesel ve küresel örgütlerin barış girişimlerinden sonuç alınamamaktadır.

Anahtar kelimeler: Ahıska, Ahıska Türkleri, Sürgün, Çıkar, Güç Dengesi.

\section{Abstract}

The issue of Ahiska Turks has very ancient roots in historical perspective although it started with their deportation on 14 November 1944. The linkage with the Russian interest is one of the most important aspects of the issue, which still remains unsolved. Ahiska Turks, who started the repatriation campaigns in 1956, have yet to accomplish many tasks. The issue, together with the collapse of the Soviet Union, gained an international status. Georgia opposes the repatriation of Ahiska Turks. But it was forced to accept the

Üsküdar University Journal of Social Sciences Year:2 Issue:2 condition of the repatriation for achieving the membership of the Council of Europe in 1999. Accordingly, Georgia, which was to complete the process of the repatriation in 2011, has deliberately tended to leave the process unsolved although it approved the law of the repatriation in this context on 11 July 2007. The parties to the issue are Georgia, Russian Federation, Turkey, as well as Meskhetian Turks. Interest is the essential factor to shape the policies for each side of the issue. However, the geostrategic position and identity of Ahiska Turks are also important in shaping the aforementioned policy. As a matter of fact, two factors in question, effective in the decision of Ahiska Turks's deportation, are enabling linkage with Russian interests. Additionally, the balance of power constituted in Caucasus in the era of post-Cold War also had an adverse impact on the solution of the issue. There can be no result of any peace initiative started by regional and global organizations just because of this absolute relation.

Keywords: Ahıska, Ahiska Turks, Deportation, Interest, Balance of Power. 


\section{Çıkar ve Güç Dengesi Kıskacındaki Ahıska Türkleri Sorunu}

\section{Giriș}

Ahıska Türkleri Sorunu'nun çözümünü birçok faktör olumsuz yönde etkilemektedir. Ancak bunlardan üçü, sorunun çözümsüzlügünde başat rol oynamaları nedeniyle daha fazla ön plana çıkmaktadır. Bu faktörlerden ilki, Ahıska'nın Rus çıkarları açısından önemidir. Bölgenin hem Sovyetler Birliği hem de RF tarafından askeri üs olarak kullanılması, Rusların Ahıska'ya verdiği önemin göstergesi olarak yorumlanabilir. Türkiye ile sınır hattı üzerinde Türklerin yaşıyor olması Rus Çarlığı tarafından tehdit olarak algılanmıştır. Söz konusu tehdidin dengelenebilmesi amacıyla, önce Osmanl1-Rus savaşlarında Osmanlı Devleti'ne ihanet eden Doğu Anadolu'daki Ermenilerin bir kısmı göç ettirilerek buraya yerleştirilmiştir. Daha sonra da, ortaya çıkan ilk firsatta buradaki Türkler sürgün edilerek tehdit ortadan kaldırılmış ve bölgede dost unsur olarak kabul edilen Ermenilerin lehine bir durum yaratılmıştır. Dönemin Gürcü Yönetimi, Stalin'in imzaladığı Sovyet Yönetimi'nin sürgün kararını destekleyerek bölgede tesis edilen yeni statünün değişmemesi için her türlü girişimde bulunmuştur. Gürcistan, bağımsızlığını kazandıktan sonra da malum tutumunu değiştirmemiş ve ülkenin diğer bölgelerine geri dönüşü kabul etmek zorunda kalsa bile Ahıska'ya yerleşime müsaade etmeme konusundaki ısrarını sürdürmektedir.

Diğer faktör, Soğuk Savaş sonrasında Güney Kafkasya'nın uluslararası sistemin bir alt bölgesi haline gelmesiyle birlikte bölgede başlayan rekabetin güç dengesiyle sonuçlanması ve bunun, sorunun çözümünü bazı yönlerden olumsuz etkilemesidir. Bu dönemde Kafkasya'daki zengin enerji kaynaklarının uluslararası pazarlara nakli için seçilen hattın Ahıska'dan geçmesi, sorun üzerinde sistemik bir baskı yaratmıştır. Geri dönüş halinde Türklerle Ermeniler arasında çatışma çıkma ihtimali ve bunun bölge istikrarını bozabilme potansiyelinden dolayı vatanlarına geri dönmek isteyen Ahıskalıların sorunu, Kafkasya'da faaliyette bulunan tüm aktörleri ilgilendirir hale gelmiştir. 


\section{Mustafa ÜREN}

Son faktör ise; sorunun çözümü için mücadele eden Ahıskalılar ile, mevcut statüyü devam ettirme adına tüm imkanlarını kullanmaktan çekinmeyen Gürcistan arasındaki eşit olmayan konum farkıdır. Mücadelenin bir tarafinda, 10 farklı ülkede oldukça dağınık bir şekilde yaşayan ve örgütlenme konusunda ciddi sorunlar yaşayan Ahıskalılar bulunurken; diğer tarafında ise, bağımsız bir devlet olan Gürcistan yer almaktadır. Asimetrik güç farkının ortaya çıktığı böyle bir ortamda, Ahıska Türklerinin başarılı olmalarını beklemek hayalcilikten başka bir şey değildir.

Görüldügüü gibi, sorunu yaratan Rusya ile bir türlü çözüme yanaşmayan Gürcistan'ın çıkarlarının aynı noktada birleşmesi, sorunun çözümünü kilitlemektedir. Bu noktadan sonra başta sistemik etki olmak üzere devreye giren her faktör sorunu biraz daha içinden çıkılamaz hale getirmiştir. Çok farklı boyutları olmakla birlikte daha çok çıkar ve güç dengesinin

Üsküdar University Journal of Social Sciences Year:2 Issue:2 kıskacında kaldığı görülen Ahıska Türkleri Sorunu'nun ele alındığı bu çalışmanın amac1; sorunu uluslararası ilişkiler parametrelerine uygun inceleyerek çözümü engelleyen faktörleri ortaya koymak, soruna taraf olan veya olmayan tüm aktörlerin yaklaşımlarını belirlemektir. Bunun için önce sorunun ortaya çıkma nedeni ve ardından günümüze kadar geçirdiği evreler özetlenecektir. Çalışmanın teorik çerçevesinin ortaya konulmasından sonra, Kafkasya'daki siyasi ortamın tanımı yapılacak ve bölgede faaliyette bulunan değişik faktörlerin soruna yaklaşımları üzerinde durulacaktır. Neticede ise, elde edilen veriler 1şığında genel bir analiz yapılarak, sorunun çözümsüzlüğünü besleyen faktörlerin daha iyi anlaşılması sağlanacaktır.

\section{Sorunu Yaratan Temel Neden: Kafkasya'nın Rus Çıkarlarına Göre Șekillendirilmesi Politikası}

Ahıska Türkleri Sorunu, Rusların güvenlik endişelerini gidermek amacıyla güneye doğru genişleme politikalarının yarattığı ve günümüze kadar devam eden sorunlardan biridir. Yaşadıkları coğrafi sınırların güney ve batı bölümlerinin dağ ve deniz gibi doğal engellere dayanmamasından dolayı Ruslar, hem Kafkasya hem de Avrupa bölgelerine yönelik güvenlik 


\section{Çıkar ve Güç Dengesi Kıskacındaki Ahıska Türkleri Sorunu}

endişesinden bir türlü kurtulamamışlardır. Rus Knezlikleri, Moskova Büyük Knezliği altında birleşinceye kadar güney ve batıdan sürekli saldırılara maruz kalmışlardır. ${ }^{1}$ Güneyinde kalan bölgeyi aynı zamanda doğal hayat sahası olarak kabul eden Ruslar, bu bölgeyi işgal ederek kara Rusyası'nın güvenliği için gerekli derinliği kazandırmışlardır.

Söz konusu niyetlerinin bir gereği olarak Rus Çarlığı, Kafkasya'nın işgaline Kuzey Kafkasya ile başlamış ve devamında Aras Nehri'ne kadar olan bölgeyi işgal etmiştir. İşgal neticesinde İran ile 10 Şubat 1828'de imzalanan Türkmençay Antlaşması'yla, daha küçük bölümü Aras Nehri'nin kuzeyinde kalacak şekilde Azerbaycan ikiye bölünmüş ve İran'da yaşayan Ermenilerin kendi rızalarıyla Rusya'ya göç etmelerine karar verilmiştir. ${ }^{2} \mathrm{Bu}$ antlaşmadan hemen sonra Osmanlı Devleti'ne savaş ilan eden Rus Çarlığı, 1828-1829 yılları arasında devam eden savaş sonucunda Kafkasya'nın geriye kalan bölümünü işgal etmiştir. Savaş neticesinde iki taraf arasında 14 Eylül 1829'da imzalanan Edirne Antlaşması'yla Anapa, Poti, Ahıska ve Ahılkelek'in savaş tazminatı karşıllğı Rusya'ya verilmiş ve asıl önemlisi de, Türkmençay Antlaşması'nda olduğu gibi, bu sefer de Doğu Anadolu'da yaşayan Ermenilerden isteyenlerin Rusya'ya göç etmelerine müsaade edilmiştir. ${ }^{3}$

Bölgenin işgalini müteakip, Kafkasya'nın Rus çıkarlarına uygun şekillendirilmesi politikası uygulanmaya konulmuştur. Bu tarihten sonra yaklaşık bir buçuk asır Rusya hakimiyetinde kalan Kafkasya, siyasi anlamda tamamen Rus çıkarlarına uygun bir biçimde şekillendirilmiştir. Söz konusu politikanın uygulanmasıyla, Kafkasya'nın Anadolu ile Türk Dünyası arasında "tampon bölge" haline getirilmesi hedeflenmiştir. ${ }^{4}$

1 Nazım Cafersoy, "Rus Jeopolitik Düşüncesinde Misyon Arayışları", Avrasya Uluslararası İlişkiler ve Stratejik Araştırmalar Dergisi, 2002, 4 (8), 51-101, s.55.

2 Okan Yeşilot, "Türkmençay Antlaşması ve Sonuçları", Türkiyat Araştırmaları Enstitüsü Dergisi, 2008, 36, 187-199, s.191.

3 Şerafettin Turan, "1829 Edirne Antlaşması”, Ankara Üniversitesi Dil ve Tarih Coğrafya Fakültesi Dergisi, 1951, 1-2 (IX), 111-151, s.191.

4 Hasan Oktay, "Kafkaslarda Barışın Önündeki Engeller ve Ermenistan", 21. Yüzyılda Türk Dünyası Uluslararası Sempozyumu Bildirileri, 02-05 Aralık 2010, (Lefke: EkoAvrasya Yayınları 2011), 317320, s. 319. 


\section{Mustafa ÜREN}

Bu maksatla, önce tampon bölgenin çekirdeği olarak "Erivan Vilayeti" oluşturulmuş ve süreç neticesinde Ermenistan Devleti kurulmuştur. ${ }^{5} \mathrm{Bu}$ süreç boyunca Ermeni toprakları, nispeten daha küçük kısmı kuzeyde bırakılan Azerbaycan aleyhine sürekli genişletilirken; bölgedeki nüfus yapısı da, Ermenilerin lehine ciddi bir şekilde değiştirilmiştir. $\mathrm{Bu}$ kapsamda Türkmençay Antlaşması gereği İran'dan göç eden Ermeniler, Erivan Vilayeti ve Dağlık Karabağ'a; yine Edirne Antlaşması gereği Doğu Anadolu'dan göç eden Ermenilerden yaklaşık 40.000'i, planlı bir şekilde Ahılkelek'e yerleştirilmiştir. ${ }^{6}$ En nihayetinde I. Dünya Savaşı döneminde Anadolu'dan göç eden Ermenilerin büyük çoğunluğu ise, Ahılkelek'in bitişiğindeki Ninotsminda'ya yerleştirilmiştir. ${ }^{7}$ Günümüzde Ahıska'nın da içinde yer aldığı Samtskhe-Cavakheti İdari Bölgesi'nin bir parçası olan Cavakheti bölgesi; Ahılkelek ve Ninotsminda ilçelerinden oluşmakta olup, nüfusunun \%95'ini Ermeniler oluşturmaktadır. ${ }^{8}$

Üsküdar University Journal of Social Sciences Year:2 Issue:2

Bölgedeki nüfus yapısının değiştirilmesiyle ilgili tüm girişimlere rağmen, tampon bölgenin biri güneyinde diğeri kuzeyinde olmak üzere iki koridorluk boşluk alan kapatılamamıştır. Buna göre, güneydeki koridor, bat1-doğu istikametindeki Nahçivan-Zengezur-Fizuli arasında kalan bölgeyi kapsamaktadır. ${ }^{9}$ Tarihçi Yerasimos bu güzergaha, Moskova Antlaşmas1 gereği Sovyetlerin Büyük Millet Meclisi Hükümeti'ne verdiği yardımlar bu bölgeden Anadolu'ya ulaştırılması nedeniyle "Íslam Koridoru" adını vermiştir. ${ }^{10}$ Yine batı-doğu istikametindeki Ahıska-Borçalı-Kazak bölgeleri arasında kalan kuzeydeki koridoru ise; Ermeni akademisyen Madoyan

\footnotetext{
5 Beşir Mustafayev, “Cihan Hakimiyetini Moskoflara Öğ̈̈tleyen Deli Petro'nun Vasiyetnamesi ve Ermenistan Devletinin Kurulmasında Etkisi”, Uluslararası Avrasya Sosyal Bilimler Dergisi, 2013, 11, 17-27, s.22.

6 Justin McCarthy, Ölüm ve Sürgün: Osmanlı Müslümanlarının Etnik Kıyımı (1821 - 1922), Çev. F. Sarıkaya, (Ankara: TTK Yayınları 2012), s.34.

7 Jonathan Wheatley, Obstacles Impending the Regional Integration of the Javakheti Region of Georgia, Working Paper No: 22, (Flensberg/Germany: Publication of ECMI 2004), p.5.

8 Hedvig Lohm, Javakhaeti After the Rose Revolution: Progress and Regress in the Pursuit of National Unity in Georgia. Working Paper No: 38, (Flensberg/Germany: Publication of ECMI 2007), p.5.

9 Hayati Aktaş ve Seyfettin Buntürk, "Güney Kafkasya'da Güç Mücadelesi ve Ahıska Türklerinin ABD'ye Göçü”, Türk Dünyası Araştırmaları Dergisi, 2007, 167, 129-142, s.142.

10 Stefanos Yerasimos, Milliyetler ve Sinırlar, 6. Baskı, (İstanbul: İletişim Yayınları 2010), s.333.
} 


\section{Çıkar ve Güç Dengesi Kıskacındaki Ahıska Türkleri Sorunu}

tarafından, Türk Dünyası'nı birbirine bağlamasından dolayı "Turan Koridoru" olarak tanımlanmıştır. ${ }^{11}$

Rus Çarlığ , tampon bölge projesini tamamlayamadan I. Dünya Savaşı döneminde yıkılmıştır. Yarıda kalan proje, ardılı Sovyetler Birliği tarafından tamamlanmıştır. Bu bağlamda yeni iktidara gelen Bolşevik Yönetimi, Kafkasya bölgesinde egemenliğini tesis eder etmez Zengezur bölgesini Ermenistan'a vermek suretiyle güneydeki koridoru kapatmıştır. ${ }^{12}$ Kuzeydeki koridor ise, II. Dünya Savaşı'nın sonuna doğru 14 Kasım 1944'de Ahıska Türklerinin sürgün edilmesiyle kapatılmıştır. Bu sayede Rusya, ilk ele geçirdiği dönemde yerleştirdiği Ermeniler vasıtasıyla bölgede sağladığ dengeyi, buradaki Türklerin sürgüne gönderilmesiyle Ermenilerin lehine değiştirmiş ve kendi çıkarları doğrultusunda geleceğe yönelik stratejik bir yatırım yapmıştır. Sürgünden sonra Sovyet Yönetimi döneminde, tüm çabalarına rağmen Ahıska Türklerinin vatanlarına geri dönüşlerine izin verilmemiş ve statüko devam ettirilmiştir. Daha da kötüsü, daha önce planlı bir şekilde buraya yerleştirilen Ermeniler, Türk düşmanlığıyla doktrine edilmişlerdir. ${ }^{13}$ Aynı tutum, Rus Askeri Üssü'nün Ahılkelek'te faaliyette bulunduğu dönemde de devam ettirilmiştir. Dolayısıyla günümüzde RF'nin de aynı anlayışa sahip olması, bölgenin Rus çıkarları açısından önem ve değerinde bir değişiklik olmadığını göstermektedir.

\section{Sorunun Tarihsel Arka Planı ve Günümüze Kadar Geçirdiği Evreler}

Ahıska Türklerinin tarihiyle ilgili yapılan çalışmalar, etnik kökenlerinin Türk boyu Kıpçaklara dayandığını göstermektedir. ${ }^{14}$ Kendileri gibi ataları Kıpçaklar da, Rusların sürgününe maruz kalmış ve bunun neticesinde

11 Hayati Aktaş ve Seyfettin Buntürk, a.g.m. s.142 ve ayrıca Orhan Uravelli, "Razdan Madoyan'1 Okurken”, Bizim Ahiska Dergisi, 2006, 6, 21-22, s.22.

12 Aygün Attar, “Zangezur İli Nasıl Ermenilerin Oldu?”, Askeri Tarih Araştırmaları Dergisi, 2003, 2, $1-10$, s.3.

13 Jonathan Wheatley, a.g.e., p.28.

14 M. Fahrettin Kırzıoğlu, Yukarı Kür ve Çoruk Boyları'nda Kıpçaklar, (Ankara: TTK Basımevi 1992), s.32. 


\section{Mustafa ÜREN}

Ahıska'ya yerleşmişlerdir. Ancak Ahıska'ya yerleşen ilk Türk boyu Kıpçaklar değildir. Onlar buraya gelmeden önce de Ahıska, asırlar boyunca birçok Türk boyu tarafından "vatan" olarak kullanılmıştır. ${ }^{15}$

Rus baskısından kaçan Kıpçakların Ahıska'ya yerleşme faaliyeti, Gürcü krallarının daveti üzerine yapılmıştır. ${ }^{16} 12$. yüzyılda iki büyük göç dalgası neticesindeAhıska'yayerleşen Kıpçaklar, bölgede 1268-1578 yılları arasında "Atabey Yurdu" adiyla kendilerine ait özel idarelerini kurmuşlardır. ${ }^{17}$ Osmanlı Devleti'nin egemenliğine girdiği 9 Ağustos 1578'den itibaren Ahıska bölgesi ve burada yaşayan Kıpçakların toplumsal yapısında, etkileri günümüze kadar devam eden önemli bazı değişimler olmuştur. Değişim kapsamında önce Hristiyanlıktan İslam dinine geçmişlerdir. ${ }^{18}$ Daha sonra, Müslüman olmalarına bağlı olarak kendilerini tanımlamada "Türk” tabirini kullanmaya başlamışlardır. ${ }^{19} \mathrm{Bu}$ dönemde Osmanlı Devleti’ne aidiyet

Üsküdar University Journal of Social Sciences Year:2 Issue:2 duygusu tamamen pekişmiştir. Kendilerini Anadolu'nun bir parçası olarak kabul ettikleri ve Ahıska'nın kesintisiz olarak yedi asırdır vatan olarak kullanıldığ1 bir dönemde, 28 Ağustos 1829'dan itibaren Rus idaresine girmek zorunda kalmışlardır. ${ }^{20}$ Ahıska Türkleri Sorunu'nun temelleri de, egemenlik değişiminin yaşandığ 1 bu dönemde atılmıştır.

Ahıska'nın Rus egemenliğine girdiği Edirne Antlaşması'nda, Rusların kendisiyle işbirliği yapan Ermenilerin haklarını teminat altına almasına karşılık, Ahıska Türkleri tamamen kendi kaderleriyle baş başa

15 M. Fahrettin Kırzıoğlu, “Ahıska Bölgesi ve Türklük”, Türk Kültürü Dergisi, 1969, 86, 203-206, s.203.

16 A. Zeki Velidi Togan, Umumi Türk Tarihine Giriş, I. Cilt, 3. Baskı, (İstanbul: Enderun Kitabevi 1981), s.200.

17 M. Fahrettin Kırzıoğlu, "Hristiyan Atabekler Hükümeti-I", Bizim Ahıska Dergisi, 2008, 10, 12-17, s.12.

18 M. Fahrettin Kırzıoğlu, Osmanlılar' 'n Kafkas-Elleri'ni Fethi, 2. Baskı, (Ankara: Türk Tarih Kurumu Basımevi 1998), s.298. Din değiştirme konusu için bakınız, A. Bican Ercilasun, "Meshet-Ahıska Türkleri Hakkında", Türkeli Dergisi, 2005, 116, s.7.

19 Ayşegül Aydıngün, "Rethinking on Ethnic Identity Formation and Shift: The Case of the Ahıska (Meskhetian) Turks", The Faculty of the Department of Sociology of Middle East Technical University, Unpublished Doctor's Thesis, Ankara 2001, s.119.

20 M. Fahrettin Kırzıoğlu, 1855 Kars Zaferi, (İstanbul: Iş̧1 Matbaası 1955), s.28. 


\section{Çıkar ve Güç Dengesi Kıskacındaki Ahıska Türkleri Sorunu}

bırakılmışlardır. $\mathrm{Bu}$ dönemde ihmal edilmelerine rağmen onlar, yine de çıkan her fırsatta tercihlerini Osmanlı Devleti'nden yana kullanmışlardır. Örneğin Rus Çarlığı'nın yıkılması üzerine yeni iktidara gelen Bolşeviklerin yayınladı̆̆ "halkların kendi kaderini belirleme hakkl” ilkesi gereği 13 Nisan 1918'de İstabul'a "Osmanlı Devleti ile birleşme isteklerine" dair bir dilekçe göndermişlerdir. ${ }^{21}$ Türkiye Cumhuriyeti'nin kurulduğu dönemde 16 Mart 1921'de imzalanan Moskova Antlaşması ile korunma altına alınmaları için yeni bir fırsat çıkmıştır. En azından Nahçivan ve Batum gibi özerk bir statüye kavuşmaları halinde, sürgün edilmeleri bu kadar kolay olmayabilirdi. Veya sürgün edilmiş olsalar bile, antlaşma çerçevesinde vatanlarına geri dönmeleri bu kadar zor olmayabilirdi.

Her iki antlaşma ile korumasız bırakılan Ahıskalıların sürgün kararında, jeostratejik ve jeopolitik faktörler etkili olmuştur. Jeostratejik faktör, Ahıska'nın Kafkasya bölgesi içindeki coğrafi konumuyla ilgilidir. Jeostratejik açıdan Ahıska, Güney Kafkasya'nın güvenliği için mutlaka elde bulundurulması gereken batı savunma hattının en kritik bölgesinde yer almaktadır. Kara Rusyası'nın güvenliği için Güney Kafkasya ne kadar önemliyse, Güney Kafkasya'nın güvenliği için de Türkiye-ErmenistanGürcistan sınırını oluşturan batı hattı da o derece önemlidir. RF'nin Kasım 2007'de Gürcistan'dan geri çekmek zorunda kaldığ1 iki askeri üssünün Batum ve Ahılkelek'te bulunması, söz konusu hattın RF açısından önemini göstermektedir. ${ }^{22}$ Ermenistan'da halen Gümrü'de konuşlu bulunan askeri üs yine bu hattın üzerinde yer almaktadır. Dolayısıyla belirtilen hat üzerinde yer alan Ahıska, doğu-batı istikametindeki stratejik ulaştırma ve askeri harekat güzergahları üzerinde bulunmasının ötesinde, aynı zamanda askeri üslenmeye de müsait bir bölgedir.

21 Y. Hikmet Bayur, Türk İnkılap Tarihi: 1914-18 Genel Savaşı/Savaşı Sonu, III. Cilt, Kısım: 4, 2. Baskı, (Ankara: TTK Basımevi 1991), s.190.

22 Jonathan Wheatley, The Integration of National Minorities in the Samtskhe-Javakheti and Kvemo Kartli Provinces of Georgia", Working Paper No: 44, (Flensberg/Germany: Publication of ECMI 2009), p.50. 


\section{Mustafa ÜREN}

Kars Yaylası ile birlikte düşünüldüğünde Ahıska'nın bölgedeki jeostratejik önemi daha da artmaktadır. Kars Yaylas1; elinde bulunduran tarafa, hem Anadolu'dan Kafkasya'ya, hem de Kafkasya'dan Anadolu'ya yapılacak askeri harekat için önemli bazı avantajlar sunmaktadır. Ahıska, her iki olasılıkta da, Kafkasya'ya açılan güzergahın başlangıç noktasında bulunmaktadır. Ahıska'nın yanında Kars Yaylası'nın da ele geçirilmesi, Rusların bölgesel çıkarları açısından iki önemli sonuç doğurmaktadır. Öncelikle sıcak denizlere ulaşma niyeti taşıyan Rus tarafına, İskenderun Körfezi'ne el atmak için uygun çıkış arazisi ve durum üstünlüğü sağlamaktadır. Nitekim 1877-78 Osmanl1-Rus Savaş1 neticesinde Rusya'nın Kars, Ardahan ve Doğu Beyazıd'a sahip olmasıyla birlikte, İngiltere'nin derhal harekete geçerek Osmanlı Devleti ile 4 Haziran 1878 'de bir antlaşma yapması ve "Kıbrıs"a yerleşmesi, Rusların malum niyetine karş1lık önleyici bir tedbir olarak düşünülebilir. ${ }^{23}$ Öte yandan, Kars

Üsküdar University Journal of Social Sciences Year:2 Issue:2 Yaylası'nın Güney Kafkasya ile birlikte Rusya'ya dahil olması halinde, Anadolu'dan Kafkasya istikametine yapılacak bir askeri harekatın kuzey yan emniyeti tehlikeye girmesine bağlı olarak başarı şansı azalabilecektir. Diğer bir ifadeyle, Kafkasya'nın batı sınırının korunması daha kolay hale gelebilecektir. Sovyetler Birliği'nin II. Dünya Savaşı'nın hemen ertesinde Türkiye'den Kars ve Ardahan'1 ihtiva eden Kars Yaylası'nı talep etmesinin altında yatan gerçek neden de budur.

II. Dünya Savaşı'nın sonuna doğru Sovyetler Birliği, Türkiye'den toprak talebinde bulunmadan önce belirtilen avantajlarından dolayı Kars Yaylası'nı askeri harekatla ele geçirmeye karar vermiş ve bunun için askeri hazırlıklara başlamıştır. ${ }^{24}$ Askeri hazırlıkların yapıldığı Ahıska'da Türklerin yaşıyor olması, Sovyet askeri harekatının başarısını tehlikeye düşürebilirdi. Bu nedenle Sovyet Yönetimi, Ahıska Türklerini sürgün etmek suretiyle bölgeyi kendisine zararlı unsurlardan temizlediği gibi, Türk Dünyası'nın

23 A. Muhtar Ataç, Rusya Tarihi: Türkler ve Komşularlyla Münasebetleri, (Ankara: Genelkurmay 1 No.11 Basımevi 1952), s.215.

24 S. Enders Wimburs ve Ronald Wixman, "Sovyet Orta Asyası'nda Yeni Bir Seda: Mesketya Türkleri”, Çev. E. Özbilen, Türk Dünyası Araştırmaları Dergisi, Ağustos 1987, 151-170, s.154. 


\section{Çıkar ve Güç Dengesi Kıskacındaki Ahıska Türkleri Sorunu}

son bağlantı noktasını da kapatmıştır. ${ }^{25}$ Sürgün neticesinde Türk-Sovyet sınırının Türk ve Müslüman niteliği tamamen değiştirilmiştir. ${ }^{26}$ Ancak gerek savaşın sonuna doğru küresel alanda meydana gelen gelişmeler, gerekse ittifak üyeleri arasında ortaya çıkmaya başlayan bazı sorunlar nedeniyle, Kars Yaylası'nın ele geçirilmesini hedefleyen askeri harekatın uygulanmasından vazgeçilmiştir.

Ahıska Türkleri, ilk olarak Orta Asya'ya değil, Doğu Gürcistan'a sürgün edilmeleri planlanmıştır. Bu nedenle Doğu Gürcistan'da yaşayan yerli Azeri ve Kürtler, zorla göç ettirilerek Kvemo Kartli bölgesine yerleştirilmiştir. ${ }^{27}$ Ancak Sovyet İçişleri Bakanı Beria'nın teklifiyle, bu bölgeye sürgün edilmelerinden vazgeçilerek Orta Asya Cumhuriyetlerine sürgünlerine karar verilmiştir. Ahıskalıların ilk planlamada topluca yerleştirilmesi için tedbir alınırken, ikinci planlamada küçük yerleşim alanlarında oldukça dağınık biçimde yaşamalarına karar verilmesi, sürgünün gerçek niyetine dair önemli ipuçları vermektedir. Buna göre, ilk planlamada asimilasyon niyetinin olmadığı; ikinci planlamadaki niyetin ise, uygulamalara bakıldığında tamamen "asimilasyon” olduğu değerlendirilmektedir. Yani sürgün kararını imzalayan Stalin, Özbekistan, Kazakistan ve Kırgızistan'ın kırsal kesimlerinde küçük gruplar halinde kamp hayatına mahkum ettiği Ahıskalıların, kardeş Türk halkları arasında kolayca asimile olacaklarını öngörmüştü. ${ }^{28}$

Sürgüne gönderilen Ahıskalıların sayısı konusunda uzmanlar arasında uzlaşma yoktur. Bu konuda çalışma yapan Türk ve yabancı uzmanlar, farklı

25 Isabelle Kreindler, "Soviet Deported Nationalities: A Summary and An Update", Soviet Studies, 1986, 38 (3), 387-405, p.392.

26 Ayşegül Aydıngün, "Ahıska (Meskhetian) Turks: Source of Confilict in the Caucasus”, International Journal of Human Rigths, 2002, 6 (2), 49-64, p.49.

27 Nana Sumbadze, "Back Home Again: The Repatriation and Integration of Meskhetian Muslims in Georgia", The Meskhetian Turks at a Crossroads: Integration, Repatriation or Resettlement Within, eds. T. Trier and A. Khanzhin, (Berlin/Germany: Publication of ECMI 2007), 288-377, p.291.

28 Kemal Özcan, “II. Dünya Savaşı Sırasında Sovyetler Birliği'nde Yaşanan Sürgün Hadiseleri”, Türk Dünyası Araştırmaları Dergisi, 2002, 141, 135-138, s.137. 


\section{Mustafa ÜREN}

rakamlar telaffuz etmektedirler. Yapılan inceleme neticesinde; sürgünden önce eli silah tutan yaklaşık 40.000 Ahıskalının ilk defa askere alındığı, daha sonra geriye kalan kadın, çocuk ve ihtiyarlardan oluşan yaklaşık 120.000 Ahıskalının da sürgüne gönderildiği tespit edilmiştir. ${ }^{29}$ Askere alınanlardan 20.000'inin cephede, sürgüne gönderilenlerden ise, 17.000'inin yollarda açlık ve soğuktan hayatını kaybettiği tahmin edilmektedir. ${ }^{30}$

Sürgünün ardından Ahıskalılar, yeni yaşam bölgelerinde tüm baskılara rağmen farklı bir halk olduklarını kanıtlamayı başarmışlardır. Bu dönemde kimliklerini tanımlamak için "Ahıska Türkleri” tabiri kullanmışlar, vatanları "Ahıska"yı da, geri dönüş mücadelesinin "birleştirici simgesi" haline getirmişlerdir. ${ }^{31} \mathrm{Bu}$ anlayışla 1956 yılından itibaren başlatılan geri dönüş mücadelesi, asimilasyon beklentisi içinde olan Sovyet Yönetimi üzerinde ciddi bir etki yaratmıştır. Bunun üzerine gelişmeleri dikkatle

Üsküdar University Journal of Social Sciences

Year:2

Issue:2 izleyen Sovyet Yönetimi, geri dönüş mücadelesinin gittikçe artan etkisini ortadan kaldırmak amacıyla, önce Ahıska Türklerinin "Müslümanlaştırılmış Gürcüler olduğu" tezini ortaya atarak Ahıska Türkleri arasındaki birlik ve beraberliği yıkmaya çalışmıştır. Başarılı olamayınca da, Haziran 1989'da yaşanan Fergana olayları devreye sokulmak suretiyle Özbekistan'da güçlü bir örgütlenmeye sahip Ahıska Türkleri, "ikinci sürgün" ile Sovyetler Birliği'nin değişik cumhuriyetlerine dağıtılmıştır. ${ }^{32}$ Sürgün, sadece bu dönemle sınırlı kalmamış, Sovyetler Birliği dağıldıktan sonra da devam etmiştir. Nitekim Fergana bölgesinden RF'nin Krasnodar Eyaleti'ne göç edenler, bölgedeki Rus yetkilerinin sistemli baskılarına dayanamayarak “üçüncü sürgün” ile, ABD’ye göç etmek zorunda kalmışlardır. ${ }^{33}$

29 Rasim Bayraktar, “Ahıska Türklerinin Dünyadaki Nüfus Dağılımı”, 2023 Dergisi, 2013, 148, 72-77, s.72. 30 Charles Blandy, The Meskhetians: Turks Or Georgian? A People without A Homeland, (Surrey/ England: Publication of Conflict Research Center 1998), p.7 ve ayrica, Şamil Kurbanov, "Ahıska Türkleri”, Azerbaycan Türk Kültür Dergisi, 1991, 279, 11-16, s.15.

31 C. Jin Oh, "Comparative Analysis of The Ahiska (Meskhetian) Turks and Koreans in Post-Soviet Kazakhstan and Uzbekistan: The Making of Diaspora Identity and Culture", Millî Folklor Uluslararası Kültür Araştırmaları Dergisi, 2012, 94, 14-26, s.14.

32 Tom Trier vd, Meskhetians: Homeward Bound, (Tbilisi/Georgia: Publication of ECMI- 2011), p.28. 33 Oleg Kuznetsov, "Constructing Identity and Social Networks: Meskhetian Turks in Russian Federation", The Meskhetian Turks at a Crossroads: Integration, Repatriation or Resettlement Within, eds. T. Trier and A. Khanzhin, (Berlin/Germany: Publication of ECMI 2007), 197-237, p.199. 


\section{Çıkar ve Güç Dengesi Kıskacındaki Ahıska Türkleri Sorunu}

Günümüzde Ahıska Türkleri RF, Ukrayna, Gürcistan, Türkiye, Azerbaycan, Özbekistan, Kazakistan, Kırgızistan, ABD ve KKTC olmak üzere 10 ayrı ülkede yaşamaktadırlar. Toplam nüfuslarının 425.000 ila 500.000 arasında olduğu iddia edilmektedir. Bu konuda alan çalışması yapan Avrupa Azınlık Sorunları Merkezi(AASM)'ne göre; Ahıskalıların, 137.000'i Kazakistan'da, 100.000'i Azerbaycan'da, 75.000'i RF'de, 35.000'i Türkiye'de, 33.000'i Kırgızistan'da, 22.500'ü Özbekistan'da, 11.500'ü ABD'de, 10.000'i Ukrayna'da ve 1.500'ü ise Gürcistan'da yaşamaktadır. ${ }^{34}$ Ahıska Türkleri Birliği(DATÜB)'nin kendi web sitesinde verdiği bilgilere göre ise, toplam nüfusları 500.000'dir.

Fergana olaylarından sonraki ikinci sürgün, Ahıskalıların geri dönüş hareketi üzerinde çok ağır bir darbe etkisi yaratmıştır. Harekete yeniden bir ivme kazandırmak amaciyla Moskova'da "Uluslararası Vatan Cemiyeti" kurulmuş olsa da, daha önceki etkinliğe bir daha ulaşılamamıştır. ${ }^{35}$ Ahıskalılar ciddi örgütlenme sorunlarıyla boğuşurken, bağımsızlı̆̆ını yeni kazanan Gürcistan'ın RF'nin yörüngesinden kurtulup Batı Dünyası'na dahil olma kapsamında Avrupa Konseyi'ne üye olması, Ahıska Türkleri Sorunu'nun çözümü konusunda önemli ilk dönüm noktasını oluşturmaktadır. 27 Nisan 1999'da Avrupa Konseyi'nin 41. üyesi olarak kabul edilen Gürcistan, söz konusu üyeliğinin devam ettirebilmek için, bazı yükümlülükler altına girmiştir. Buna göre, öncelikle, üyelik tarihinin başlangıcından itibaren en geç 2002 yılına kadar geri dönüşü düzenleyen bir kanun hazırlayarak yürürlüğe girmesini sağlayacaktır. Daha sonra, hazırlanacak söz konusu kanun esaslarına uygun olarak geri dönüş faaliyeti, 12 yıl içinde veya en geç 2011 yılına kadar tamamlanacaktır. Gürcistan, her iki şartı da kabul ettiğine dair hazırlanan belgeyi Nisan 1999'da imzalayarak Avrupa Konseyi'ne karşı taahhütte bulunmuştur. ${ }^{36}$

34 Tom Trier vd, a.g.e., p.56.

35 Arif Yunusov, Meskhetian Turks: Twice Deported People, (Baku: The Research Document Published by The Institute of Peace and Democracy 2000), p.37.

36 Alexander Osipov, Russian Experience of Ethnic Discrimination: Meskhetians in Krasnodar Region, (Moscow/RF: The Report Published By Memorial Human Rights Center 2000), p.57. 


\section{Mustafa ÜREN}

Avrupa Konseyi'ne üye olma şartının bir gereği olarak Gürcistan'ın 11 Temmuz 2007 tarihinde geri dönüş yasasını onaylaması, geri dönüş mücadelesinde ikinci dönüm noktasıdır. ${ }^{37}$ Bunun neticesinde geri dönüş hareketinde gözle görülür bir canlanma olmuştur. $\mathrm{Bu}$ dönemde Ahıska Türkleri, Gürcistan üzerinde gerekli baskının oluşturabilmesi ve uluslararası ortamda etkin bir mücadele verilebilmesi amaciyla 18 Kasım 2008'de yeni bir örgüt çatısı altında birleşme kararı almıştır. ${ }^{38} \mathrm{Bu}$ maksatla Türkiye'nin de desteğiyle oluşturulan çatı örgütü DATÜB'ün kuruluş felsefesi olarak sağlam temellere dayandırıldığ 1 söylenebilir. Bu olumlu başlangıca karşın zaman içinde kurumsal bir yeteneğe kavuşturulamaması nedeniyle etkinliği giderek zayıflamıştır.

Gürcistan'ın onaylayarak uygulamaya koyduğu geri dönüş yasası gereği 2008-2010 yılları arasında yapılan geri dönüş müracaatları DATÜB'ün de

Üsküdar University Journal of Social Sciences Year:2 Issue:2 Ahıskalılar üzerindeki etkinliğinin bir testi olmuştur. DATÜB ve Ahıskalı derneklerin sürekli geri dönüş özleminden bahsetmelerine karşılık, sonuç beklentilerin tam tersi çıkmıştır. Geri dönüş için müracaat eden Ahıska Türklerinin toplam miktarının yaklaşık 9.800 olduğu tespit edilmiştir. ${ }^{39} \mathrm{Bu}$ sonuç Ahıska Türklerinin toplam miktarı ile mukayese edildiğinde, geri dönmek isteyenlerin \%2'nin bile altında kaldığ 1 anlaşılmaktadır. Ortaya çıkan bu oran; temsil organları olan derneklerin söylemiyle Ahıskalıların eylemleri arasındaki çelişkiyi ortaya koyduğu kadar, DATÜB'ün de temsil ettiğini iddia ettiği halk üzerindeki etkinliğinin ne derece zayıf olduğunun da bir göstergesi olmuştur.

Başarısız olarak nitelendirilebilecek bu sonuçtan dolayı Ahıskalıları suçlamak yerine, bu sonuca neden olan faktörlerin iyi anlaşılması gerekmektedir. Günümüzde farklı ülkelerde dağınık bir şekilde yaşamak zorunda bırakılan Ahıskalıların Gürcistan ile mücadele etmelerinin

37 Ayşegül Aydıngün, Ahıska Türklerinin Gürcistan'a Dönüşü, (Ankara: ASAM Yayını No: 6 2008), s.8. 38 A. Tacıbayeva, "68 Yıldır 10 Ayrı Ülkede Vatan Hasreti Çekiyoruz”, İpekyolu Gezi ve Kültür Dergisi, 2013, 16, 38-45, s.39.

39 Dünya Ahıska Türkleri Birliği, DATÜB 2010-2014 Faaliyetleri, (Ankara: DATÜB Yayını 2014), s.16. 


\section{Çıkar ve Güç Dengesi Kıskacındaki Ahıska Türkleri Sorunu}

zorlukları ortadadır. Üstelik geri dönmek istedikleri Ahıska'nın da içinde yer aldığı Kafkasya, sahip olduğu doğal kaynakları nedeniyle bölgesel ve küresel güçlerin ilgi odağı haline gelmiştir. Bu kapsamda Ahıska'nın enerji hatlarının geçeceği güzergah üzerinde yer aldığının ortaya çıkması, şartları Ahıskalıların aleyhine daha da zorlaştırmıştır. Bu son gelişmeyle, hem uluslararası sistemin hem de Kafkasya'daki rekabete dahil olan yeni aktörlerin Ahıska Türkleri Sorunu'nun çözümüne olumsuz bazı yansımaları olmuştur.

Bahse konu olumsuz yansımaların daha iyi anlaşılabilmesi amacıyla, öncelikle Kafkasya'daki siyasi ortam tanımlanacak ve ardından bu ortamda faaliyette bulunan tüm aktörlerin soruna yönelik yaklaşımları ortaya konulacaktır. Her iki aşama teorik çerçeveye uygun olarak gerçekleştirilecek, bunun neticesinde sistemik etki dahil bölgedeki aktörlerin farklı yaklaşımlarından dolayı sorunun çözümsüzlüğ̈̈nü besleyen faktörlerin bir bütün halinde anlaşılması sağlanacak ve nihayetinde de tüm bu gelişmelerin Ahıskalıların geri dönüş hareketi üzerinde ne gibi etkiler yarattığ hususunda durum tespiti yapılacaktır.

\section{İncelemede Kullanılacak Teorik Paradigma}

Post Sovyet döneminin başlangıcından itibaren Kafkasya; jeostratejik önemi ve sahip olduğu zengin enerji kaynakları nedeniyle ABD gibi küresel, RF, Türkiye ve İran gibi bölgesel güçlerin rekabetine sahne olmuştur. Güce dayalı politika anlayışının hakim olduğu bölgedeki politik ortamın tanımlanması ve açıklanmasında realist paradigmanın daha başarılı olduğu düşünülmektedir.

Rasyonel metodolojiye uygun olarak inşa edilen realist paradigma, analiz seviyelerinde meydana gelen farklılaşmalardan dolayı sırasıyla klasik realizm, neorealizm ve neoklasik realizm olmak üzere üç akıma ayrılmıştır. ${ }^{40}$ Belirtilen üç realist akım arasında neorealist paradigmanın; sistem, yapı,

40 Thomas Diez vd, Key Concepts in International Relations, (London/UK: SAGE Publications 2011). p.178. 


\section{Mustafa ÜREN}

güvenlik, güvenlik ikilemi, kendi kendine yeterli olma ilkesi, güç, ittifak oluşturma, güç dengesi ve hegemonya gibi önermeleri vasıtasıyla gerek Kafkasya'daki siyasi ortamı gerekse bu ortamdaki aktörlerin davranışlarını daha iyi açıkladığı görülmektedir. Bu yüzden, çalışmanın teorik alt yapısı olarak neorealist paradigmanın kullanılmasına karar verilmiştir.

Neorealist paradigma esaslarına göre; uluslararası sistem, yapı ve sürekli karşı1ıklı etkileşim halinde bulunan parçalardan oluşmaktadır. Parçalar, uluslararası sistemin temel aktörleri olarak kabul edilen devletlerdir. Yap1 ise, devletlerin sistem içinde sıralandırılmalarıyla ortaya çıkan soyut bir mekanizmadır. ${ }^{41}$ Yapının asli özelliklerinden biri, sahip oldukları kapasitelere göre kendi aralarında sıralanan devletlerden bağımsız bir şekilde uluslararası sisteme bütünlük kazandırmasıdır. ${ }^{42}$

Üsküdar University Journal of Social Sciences Year:2 Issue:2

Devletler, uluslararası sistem içinde benzer birimler olarak kabul edilirler. ${ }^{43}$ Devletlerin benzerlikleri, egemen eşitlik ilkesi çerçevesinde yerine getirdikleri görev veya fonksiyonların aynı olmasıyla ilgilidir. ${ }^{44}$ Bu durum, mevcut yapının aktörler üzerindeki "aynılaştırıcı etkisi”nden kaynaklanmaktadır. Yani devletlerin yönetim şekilleri ve takip ettikleri dış politikalarının kimin tarafından hazırlanıp uygulandığı önemli değildir. $\mathrm{Bu}$ açıdan devletler, adeta kara kutu gibi bütüncül varlıklar olarak kabul edilirler. $^{45}$

Devletlerin birbirlerine göre farklılığını, sahip oldukları kapasiteleri belirlemektedir. Devletlerin kapasiteleri, güç olarak tanımlanmaktadır. Devletlerin güçlerindeki değişiklik, sistemdeki sıralamaya doğrudan etki etmekte ve yapı değişikliğine neden olmaktadır. Söz konusu yapısal

41 Kenneth N. Waltz, Theory of International Politics, (California/USA: Addison-Wesley Publishing Company 1979), p.79.

42 Atila Eralp, "Sistem”, Devlet ve Ötesi İçinde (9. Baskl), (Ankara: İletişim Yayınları 2012), 125-153, s.138. 43 Kenneth N. Waltz, "Realist Thought and Neorealist Theory". The Journal of International Affairs, 1990, 44(1), 21-37, p.37.

44 Kenneth N. Waltz, 1979, a.g.e., p.93.

45 John J. Mearsheimer, "Structural Realism", International Relations Theories: Discipline and Diversity. eds. T. Dunne, M. Kurki and S. Smith. (Oxford/England: Oxford University Pres 2007). 71-88, p.72. 


\section{Çıkar ve Güç Dengesi Kıskacındaki Ahıska Türkleri Sorunu}

değişikliğin ancak sistemdeki büyük güçler tarafindan yapılabileceğine inanılmaktadır. ${ }^{46}$

Aktörler arasındaki ilişkileri düzenleyen hakim bir otorite olmaması nedeniyle uluslararası sistemin yapısı anarşiktir. Anarşik sistem içinde aktörler, diğer aktörlerin faaliyetlerini sınırlamaktan kaçınmaktadırlar. Hiyerarşik olmayan böyle bir ortamda aktörler, güvenlik konusuna öncelik vermek zorundadırlar. Güvenliklerini kendi kendilerine sağlamaları dışında başka bir seçenekleri yoktur. Bu yüzden anarşik yapı içinde her aktör için kendi kendine yeterli olma ilkesi geçerlidir. ${ }^{47}$ Güvenlik ihtiyacını sorunsuz bir şekilde karşılayabilen aktörler, güçleriyle orantılı olarak daha sonra huzur, kazanç ve güç gibi diğer hedeflere de yönelebilirler. ${ }^{48}$

Anarşik sistem içinde devletler arasındaki ilişkilerde, belirsizlik ve şüphe hakimdir. Bu nitelikteki bir ortam, genellikle güvenlik ikilemi kavramı ile açıklanmaktadır. ${ }^{49}$ Söz konusu kavrama göre, güvenlik endişelerini gidermek amacıyla bir tarafın gücünü artırmak için silahlanması, diğer tarafın silahlanmasını tetiklemektedir. Bu nedenle anarşik sistem içinde doğal durum, savaş hali durumu olarak kabul edilmektedir. Ancak bu, uluslararası sistemde her zaman savaş çıkabilir anlamına gelmemekte, devletler arasında sorun çıkması halinde bir devletin tek başına savaş kararı alabileceğini göstermektedir. ${ }^{50}$ Böyle durumlarda uluslararası sistem içinde çözüm için oluşturulan mekanizmalar işe yaramamaktadır. Yani uluslararası kurumların sorunları çözme kabiliyetleri yoktur. Herhangi bir sorun çıktığında düzeni sağlayacak otoriteleri ve saldırganı cezalandıracak yetenekleri olmamaları nedeniyle uluslararası kurumlar pek fazla bir şey yapamamaktadirlar..$^{51}$

46 Kenneth N. Waltz, 1979, a.g.e., p.93.

47 A.g.e., p.88.

48 A.g.e., p.126.

49 Andrew Heywood, Global Politics, (New York/USA: Broadcasting of Palgrave Macmillan 2011), p.60. 50 Kenneth N. Waltz, a.g.e., p.102.

51 John J. Mearsheimer, "Back to The Future: Instability in Europe After The Cold War", International Security, 1990, 25(1), 5-56, p.12. 


\section{Mustafa ÜREN}

Uluslararası sistem içinde diğer devletlere göre zayıf olduklarını düşünen devletler için çözüm, güçlerini artırmak veya diğer devletlerle birleşerek güçlerini çoğaltmaktır. Gücü çoğaltmak amacıyla ittifak oluşturulmasında, güçlü üyenin merhametine sığınma yerine dengeleme esas alınmalıdır. ${ }^{52}$ Zaten uluslararası anarşik sistem de, göreceli güce önem verilmemesi ve işbirliğine endişeyle yaklaşılma hususunu devletlere dikte ettirmektedir. Zaten hiçbir devlet, işbirliği neticesinde birlikte elde edilecek ortak kazancın kendisine karşı kullanılmayacağından emin değildir. ${ }^{53}$

Devletler arasında ortaya çıkan rekabetin çatışmaya dönüşmesini, güç dengesi engellemektedir. Kavram olarak güç dengesi, uluslararası sistemde veya ona bağlı bir alt sistem içinde denge eğiliminin hakim olduğu siyasi koşulları tanımlamaktadır. Böyle bir ortamda, hegemonik arzular mümkün olduğunca törpülendiği için hiçbir devletin diğerlerine üstünlük sağlama olanağ 1 yoktur. ${ }^{54}$ Güç dengesi teorisine göre; uluslararası sistem içinde güç

Üsküdar University Journal of Social Sciences Year:2 Issue:2 dengesi, asgari düzeyde hayatta kalma, azami düzeyde ise küresel hakimiyet sağlama amaçlarına hizmet eder. Bu kapsamda uluslararası sistemin temel aktörleri devletlerin belirtilen amaçlarına ulaşabilmeleri için uygun araç ve yöntemleri kullanma gayretleri neticesinde güç dengesi kendiliğinden ortaya çıkmaktadır. ${ }^{55}$ Denge sağlandığında, temel hedef mümkün olduğunca devam ettirilmesidir. Bozulduğunda ise; uygun olan bir yöntemle, en kısa sürede tekrar eski haline getirilmeye çalışılır. Buradan da anlaşılacağ 1 gibi, rekabete dayalı uluslararası sistem içinde güç dengeleri tekrar tekrar yeniden oluşmaktadır. ${ }^{56}$ Güç dengesinin sağlanmasıyla sistem içinde elde edilmek istenen nihai sonuç istikrardır. Diğer bir ifadeyle, güç dengesinin sağlanmasına bağlı olarak istikrar, sistem tarafindan her seferinde yeniden üretilmektedir. $^{57}$

52 Kenneth N. Waltz, a.g.e., p.126.

53 Kenneth N. Waltz, a.g.e., p.106.

54 Andrew Heywood, a.g.e., p.309.

55 Kenneth N. Waltz, a.g.e., p.118.

56 Kenneth N. Waltz, “Uluslararası İlişskiler Kuramı”. Uluslararası İlişkiler Kuramı ve Dünya Siyasal Sistemi İçinde, Çev. E. Onulduran, (Ankara: AÜ SBF Yayınları No: 510 1982), 3-95, s.48.

57 H. Basri Yalçın, "Uluslararası Sistem ve İstikrar: Kavramsal Bir Değerlendirme", Akademik Incelemeler Dergisi, 2015, 10(1), 209-229, s.215. 


\section{Çıkar ve Güç Dengesi Kıskacındaki Ahıska Türkleri Sorunu}

Kenneth Waltz'a göre; zayıf devletlerin, yeni güç dengesinin oluştuğu dönemlerde güçlü devletlerin "peşine takılma" yönünde karar almaları yanlıştır. ${ }^{58}$ Böyle bir durumda zayıf devletlerin, güçlü bir devletin peşine takılma yerine "beka veya varlığını devam ettirme" konusuna öncelik vermesi daha doğrudur. Buna göre; zayıf devletler, yeni güç dengesinin hangi tarafında yer alacaklarına kendi çıkarlarına uygun bir şekilde karar vermelidirler. Aksi takdirde, özellikle hayati durumlarda güçlü devletin merhametine sığınma dışında bir seçenekleri kalmayacaktır. Yani güç dengesini sağlayan ittifak oluşturma sürecinde müttefikler arasındaki işbirliği, zayıf olanın güçlüye bağımlı hale gelmesiyle sonuçlanabilecektir. ${ }^{59}$ Aynı konuya değinen John Mearsheimer ise; güç dengesinin, güçlü devletlerin dayatmaları neticesinde zayıf devletlerin genellikle bağımlı hale gelmesine neden olduğunu iddia etmektedir. Bu durumda, küçük devletlerin güç dengesinin her iki tarafındaki güçlü devletlere karşı kullanabileceği pek fazla seçenekleri kalmamaktadır. ${ }^{60} \mathrm{Bu}$ yüzden küçük devletler, çoğu kez bağımsızlıklarını kaybetme riskiyle karşı karşıya kalmaktadırlar.

\section{Kafkasya'da Faaliyette Bulunan Aktörlerin Soruna Yaklașımı}

Sovyetler Birliği'nin tarihe karışmasından en fazla etkilenen bölgelerin başında Kafkasya yer almıştır. Bunun en önemli nedenlerinden biri, bölgedeki etnik çatışmalar ise, diğeri de Hazar Denizi’ndeki zengin enerji kaynaklarının dünya pazarlarına aktarılması konusunda yaşanan rekabettir. Bu alanda taraflar arasındaki rekabet kısa sürede güç dengesiyle sonuçlanmıştır. Bölgede oluşan güç dengesinin "neorealist paradigma"nın önermelerine uygun oluştuğunu söyleyebiliriz. Buna göre, dengenin bir tarafında küresel güç olarak kabul edilen $\mathrm{ABD}$; diğer tarafında ise, bölgenin tartışılmaz gücü olarak kabul edilen RF yer almaktadır. $\mathrm{Bu}$ dönemde bağımsızlığını kazanarak uluslararası sisteme dahil olan Azerbaycan, Gürcistan ve Ermenistan'ın üçü de başlangıçta güvenlik, güvenlik ikilemi,

58 Kenneth N. Waltz, 1979, a.g.e., p.126.

59 A.g.e., p. 106.

60 John J. Mearsheimer, 1990, a.g.m., p.14. 


\section{Mustafa ÜREN}

beka veya varlığını devam ettirme gibi konularda ciddi sorun yaşamışlardır. Üçünün de güçlerini çoğaltma dışında başka seçenekleri bulunmamaktaydı. $\mathrm{Bu}$ nedenle Azerbaycan ve Gürcistan, çıkarlarına uygun olarak ABD tarafında olmay1; diğer aktör Ermenistan ise, Mearsheimer'ın 'güçlü devletlerin biat taleplerinin kabul edilmesi zaylf devletleri bağımlı hale getirebilir" uyarısına rağmen RF'nin hamiliğini tercih etmiştir. Soğuk Savaş döneminde olduğu gibi, yine nükleer silahların büyük rol oynadığı Kafkasya'daki yeni güç dengesini sağlayan iki ittifakın bir tarafında, ABD, Türkiye, Azerbaycan ve Gürcistan'ın; diğer tarafında ise, RF, İran ve Ermenistan'ın yer aldığı görülmektedir. ${ }^{61}$ Bölgedeki güç dengesini sağlayan iki ittifaka teorik çerçeveden bakıldığında, ABD tarafının bölgedeki mevcut yapının devamından yana statükocu; RF tarafının ise, tam tersine değişiminden yana revizyonist bir politika takip ettikleri söylenebilir.

Üsküdar University Journal of Social Sciences Year:2 Issue:2

Neorealist paradigma, enerji güvenliğini "sıfir toplamlı bir oyun” olarak kabul etmektedir. Oyunda kazanan taraf, diğer tarafa karşı göreceli olarak avantaj sağlamaktadır. ${ }^{62}$ Ancak söz konusu avantajın bölgenin istikrarına olumsuz yansıması halinde bundan iki tarafın da zarar göreceğinin farkında olan ittifak liderleri $A B D$ ve RF, enerji hatlarının geçtiği bölgelerin güvenliği ve istikrarına önem vermektedirler. Bununla birlikte hem $A B D$, hem de RF, enerji hatlarının güvenliği konusunda rakip tarafın söz sahibi olabilir endişesinden bir türlü kurtulamamaktadırlar. Böyle bir durumda, enerji güvenliğinin tehlikeye girmesiyle bölgedeki istikrarın bozulabileceği ihtimali, güç dengesinin hassasiyetini artırmakta ve tarafları daha dikkatli davranmaya zorlamaktadır. Örneğin RF'nin Ahılkelek'teki Ermeniler vasıtasıyla Bakü-Tiflis-Ceyhan Hattı'nın geçtiği kritik bölgelerden biri olan Ahıska'nın istikrarını etkileyebilme potansiyeli ona göreceli olarak büyük avantaj sağlamakta ve ABD’nin bölgedeki politikalarını doğrudan etkileyebilmektedir.

61 Geoffrey Gresh, "Coddling The Caucasus: Iran's Strategic Relationship with Azerbaijan and Armenia", Caucasian Review of International Affairs, 2006, 1(1), 1-13, p.10.

62 Sascha Kuhn vd, Energy Cooperation in the Caucasus: Continuity and Change in Russian-Turkish Relations, .(Malmö/Sweden: A Report Published by Malmö University 2010), p.11. 


\section{Çıkar ve Güç Dengesi Kıskacındaki Ahıska Türkleri Sorunu}

Kafkasya'daki ortamın siyasi, güvenlik ve jeopolitik açılardan değerlendirilmesinde RF'nin Ermenistan'da konuşlu “Askeri Üs”sünün etkisini unutmamak gerekmektedir. Askeri Üssün, bu kapsamdaki analizleri üç yönden etkilediği görülmektedir. Öncelikle, Askeri Üssün sağladığı avantajları çok iyi kullanma eğiliminde olan RF, güç dengesinin hassasiyetlerine riayet etse de, bölgenin hegemonik gücü gibi davranabilmektedir. ${ }^{63}$ Böyle bir yaklaşım bölgesel ve küresel örgütlerin Kafkasya'daki etkinliğini zayıflatmaktadır. Bu durum, genellikle bölge devletlerinin üyesi olduğu Avrupa Konseyi ve AGİT gibi örgütlerin gündeme getirdiği barış projelerinin başarılı olmaması şeklinde kendini hissettirmektedir. Mesela AGİT'in Dağlık Karabağ Sorunu'nun çözümü için yaptığı arabuluculuk girişimlerinden olumlu bir sonuç alınamamıştır. RF'nin son dönemdeki Gürcistan ve Ukrayna'ya müdahaleleri, mevcut durumu daha da kötüleştirmiştir. Diğer taraftan Askeri Üsse ev sahipliği yapan Ermenistan, gücüyle orantılı olmayan bir politika takip edebilmektedir. Rusların örtülü desteğiyle işgal ettiği Azerbaycan topraklarından çekilmeyi reddedebilmekte ve kendi çıkarlarına uymayan barış girişimlerini kabul etmeme konusunda 1srarcı olabilmektedir. En önemlisi de, bölgedeki Rus askeri varlığından güç alan bazı azınlık gruplar, merkezi yönetime karşı daha cesaretli bir tutum sergileyebilmektedirler. Bunun en somut örneği, Cavakheti Ermenileridir. Kendilerini Gürcistan'dan daha çok Ermenistan'ın bir parçası gibi gören Cavakheti'deki Ermeniler, bölgeyle ilgili niyetlerinin gerçekleşmesini engelleyebilecek olmalarından dolayı Ahıska Türklerinin vatanlarına geri dönüşüne itiraz etmektedirler.

Kafkasya'da tanımlanan siyasi ortam içinde Ahıska Türkleri Sorunu'nun çözümünde söz sahibi olan asli aktörler Gürcistan, RF ve Türkiye'dir. Ad1 geçen üç ülke, siyasi, tarihi, sosyal ve kültürel bağlarından dolayı sorunun tarafıdırlar. ${ }^{64}$ Onlar da dahil olmak üzere bölgedeki tüm aktörlerin soruna

63 Ergin Güneş, “Tehdit Algılamaları Ekseninde Rusya’nın Yakın Dönem Kafkasya ve Orta Asya Politikası", Akdeniz I.I.'B.F. Dergisi, 2013, 27, 176-203, s.178.

64 Muhsin Yazıcığlu, “Ahıska Türkleri Meselesi Milli Bir Davadır”, Bizim Ahıska Dergisi, 2007, 7, 11-12, s. 11 . 


\section{Mustafa ÜREN}

yaklaşımlarında, çıkarlarıyla bağlantılı olarak Ahıska'nın jeopolitik önemi etkili olmaktadır. Jeopolitik faktör kadar olmasa da, Ahıska Türklerinin kimliklerinin de etkili olduğu görülmektedir. Kimlik konusu, Sovyet Yönetimi'nin, sürgün kararının alınmasında birinci derece etken olduğu gibi, daha sonra Ahıskalılara karşı uyguladığı zayıflatma stratejisinin de bir parçası olarak kullanılmıştır. Bu kapsamda Ahıskalıların geri dönüş mücadelesinin etkinliğinin artmasına bağlı olarak "Ahıskalıların, Osmanlı Devleti tarafindan önce Müslümanlaştırılan, daha sonra da Türkleştirilen Müslüman Gürcüler" olduğunu öngören "Gürcü Tezi” devreye sokulmuştur. ${ }^{65}$ Ahıskalılar arasındaki birlik ve beraberliğin bozulmasını hedefleyen söz konusu stratejiden umut edilen başarı tam olarak elde edilememiştir. $\mathrm{Bu}$ olumsuz sonuca karşın Gürcistan, selefinden miras olarak devraldığı zayıflatma stratejisinin uygulanmasından günümüzde de vazgeçmemekte ve özellikle uluslararası ortamda kısmen de olsa başarılı sonuçlar almaktadır.

Usküdar

Journal of

Uluslararası sisteme siyasi bütünlüğünü kaybetme endişesiyle dahil olan Gürcistan, komşusu Azerbaycan gibi Batı Dünyası'nın yanında yer almayı tercih etmiştir. $\mathrm{Bu}$ dönemde ülkenin bekasıyla ilgili Abhazya ve Güney Osetya sorunlarını, RF'nin desteği sayesinde çözüme kavuşturabilmiştir. Ancak bu alandaki endişelerini giderir gidermez, bölgede oluşan güç dengesinde ABD'nin tarafinda yer almıştır. Bu tutumuna paralel olarak ülkesinden geçmesi planlanan enerji hatlarıla ilgili girişimlerde de ABD'nin projelerini desteklemiştir.

Gürcistan, gerek bölgeyle gerekse ülkesiyle ilgili konularda RF ile anlayış farkına sahiptir. Ahıska Türkleri Sorunu, bunun bir istisnasıdır. İki tarafın politikaları bu konuda uyuşmaktadır. Gürcü Yönetimi, Sovyetler Birliği döneminde olduğu gibi bağımsızlığını kazandıktan sonra da geri dönüşe karş1 olumsuz tutumunu değiştirmemiştir. Türkiye ile sınır bölgesinde yeni bir azınlık grup istememektedir. Bu nedenle geri dönüş

65 Oskari Pentikainen and Tom Trier, Between Integration and Resettlement: The Meskhetian Turks, Working Paper No: 21, (Flensberg/Germany: Publication of ECMI 2004), p.9. 


\section{Çıkar ve Güç Dengesi Kıskacındaki Ahıska Türkleri Sorunu}

projesi için ülkesinin ekonomik durumunun uygun olmadığı, halen mülteci konumundaki yaklaşık 300.000 Gürcünün yerleşim sorunlarına çözüm getirilemediği, daha da önemlisi geri dönmeleri halinde Türklerle Ermeniler arasında etnik bir çatışma çıkabileceği gibi mazeretler ileri sürmektedir. ${ }^{66}$

Ahıska Türklerinin "Müslümanlaştırllmış Gürcüler olduğu” tezini her firsatta gündeme getiren Gürcistan, Sovyetler Birliği'nden miras aldığ 1 bu iddiasına Avrupa Konseyi'nin baskısıyla geri dönüş yasasını onaylayıncaya kadar devam etmiştir. Bu dönemde çok az da olsa geri dönme şansını yakalayan Ahıskalıların tamamı, Gürcü Yönetimi'nin koyduğu "Gürcü olduklarını kabul etmeleri ve Gürcü soyadı almaları” şartını kabul ederek Gürcüce soyadlarını almak zorunda kalmışlardır. ${ }^{67}$ Yasayı kabul etmekle birlikte uygulanmasında keyfi davranan Gürcistan, geri dönüşü onaylananların ülkenin farklı bölgelerine yerleştirileceğini, ancak Ahıska'ya geri dönüşe kesinlikle müsaade etmeyeceğini her platformda dile getirmektedir. Aslında bu konudaki yaklaşımı, Avrupa Konseyi'nin 1428 sayılı kararına (Geri dönüşün Ahıska'ya yapılacağını öngörmektedir.) aykırıdır. ${ }^{68} \mathrm{Bu}$ somut hukuki gerçeğe rağmen, kararlı tutumunda bir değişiklik olacağına dair olumlu bir emare yoktur.

RF açısından Kafkasya, hem kara Rusyası'nın güvenliğine derinlik kazandırılması hem de, hayat sahası olarak son derece önemlidir. Yakın Çevre Doktrini kapsamında bölgede oluşturduğu siyasi ortam, Kafkasya'daki tüm sorunların çözümünde kendisine özel bir statü sağlamaktadır. Bu özel statünün en fazla hissedildiği dönemlerden biri, hiç şüphesiz Ağustos 2008'de Gürcistan'a müdahalesidir. Hegemonik bir güç gibi davranma eğilimin en somut örneklerinden birini oluşturan bu dönemde bazı yabancı uzman ve gözlemciler, RF'nin Gürcistan üzerinde baskı kurmak

66 Roin Kavrelişvili, “Güney Gürcistan'dan Sürgüne Gönderilen Toplulukların Geriye Dönüş Yolundaki Hukuki Durumu”, Uluslararası Ahıskalı Türklerin Hukuki ve Sosyal Sorunları Sempozyumu İçinde, ed. R. Bayraktar, (Ankara: Astana Yayınları, 2014), 45-50, s.48.

67 Seyfettin Buntürk, Rus Türk Mücadelesinde Ahiska Türkleri, (Ankara: Berikan Yayınevi 2007). s.404.

68 Ayşegül Aydıngün, “Ahıska Türklerinin Dünü, Bugünü ve Yarını", Yeni Türkiye Dergisi Türk Dünyası Özel Saylsı II, 2013, 54, 2665-2674, s.2672. 


\section{Mustafa ÜREN}

amacıyla gerekirse Cavakheti bölgesindeki ayrılıcçıları kullanabileceği ve bu suretle bölgeyi istikrarsızlaştırabileceği iddiasında bulunmuşlardır. ${ }^{69}$ Uluslararası uzmanların dikkat çektiği Rus ve Ermeni işbirliği tehdidi, öngörüldüğü şekilde uygulamaya konmamıştır. Ancak Ahıska Türklerinin geriye dönmeye başlamalarıyla birlikte uygulanmayacağını kimse garanti edemez. Bu yüzden geri dönüşün etnik çatışmaya dönüş̧ebileceği ve bunun bölgedeki istikrarı bozabileceği ihtimali, bölgede güç dengesinin tesis ettiği istikrara tehdit oluşturmaktadır. Başka bir ifadeyle, Rus çıkarları açısından son derece önemli olan Ahıska'daki demografik yapının Ermenilerin aleyhine bozulmasına RF'nin tepkisiz kalmayacağı ihtimalinin oldukça yüksek olması, Kafkasya' daki tüm aktörlerin soruna yönelik politikalarını etkileyebilmektedir. Zaten bölgesel istikrarın bozulma olasılığına bağlı olarak sistemik etki de bu noktada devreye girmektedir.

RF, Ahıska'da Ermenilerin lehine olan mevcut statünün kendi çıkarlarıyla

Üsküdar University Journal of Social Sciences Year:2 Issue:2 uyumlu olması nedeniyle ne Ahıska Türkleri Sorunu'nun çözümünde herhangi bir rol almayı, ne de geri dönüş konusunda bir sorumluluk almayı düşünmektedir. ${ }^{70}$ Genellikle sorunu, Gürcistan'a karşı bir bask1 vasıtası gibi kullanma görüntüsü içindedir. Ahıska Türklerinin başta Gürcistan olmak üzere istedikleri ülkeye gitme haklarının olduğunu söylese de, gerçekte Ahıska Türklerinin vatanlarına geri dönüşlerine karşıdır. Krasnodar Eyaleti'ndeki baskılar sonucunda 2004 y1lında neden olduğu "üçüncü sürgün" ile bu konuya yönelik tutumunu alenen ortaya koymuştur. ${ }^{71}$ Ahıska bölgesiyle ilgili çıkarları göz önünde bulundurulduğunda, Gürcistan Ahıska'ya geri dönüşü kabul etse bile, RF'nin söz konusu faaliyeti engellemek amaciyla Cavakheti' deki Ermenileri kullanarak olaya müdahale etmede tereddüt göstermeyeceği düşünülmektedir.

RF'nin bölgedeki hegemonik yaklaşımından rahatsızlık duyan Türkiye, güç dengesini sağlayan iki ittifak arasında II. Dünya Savaşı'ndan sonraki

69 International Crisis Group(ICG), Georgia: The Javakheti Region’s Integration Challenges, (Brussels/ Belgium: Europe Briefing No: 63 2011), p.3.

70 Andrei Khanzhin, "Durable Solutions for Meskhetian Turks: The issue revisited", European Yearbook of Minority Issues, 2004, 4(5), 495-511, p.506.

71 Ayşegül Aydıngün vd, Meskhetian Turks, Culture Profile No: 20, (Washington/USA: Publication of The Center for Applied Linguistics 2006), p.10. 


\section{Çıkar ve Güç Dengesi Kıskacındaki Ahıska Türkleri Sorunu}

dönemde olduğu gibi yine ABD’nin yanında yer almıştır. Türkiye, Kafkasya'daki istikrarsızlığın yarattığı sonuçlardan en fazla etkilenen ülkelerin biridir. $\mathrm{Bu}$ nedenle güç dengesinin hassasiyetlerine zarar vermekten kaçınmaktadır. Buna bağlı olarak da, Ahıska Türkleri Sorunu'yla ilgili politikasını ittifak ilişkilerine yansıtmama eğilimindedir.

Resmi kayıtlara göre, Türkiye'nin Ahıska Türklerinin sürgün edilmesinden haberinin olup olmadığı bilinmemektedir. Sorundan ilk defa, Ahıskalı liderlerin 6 Nisan 1970'de Türkiye'ye göç etmelerine müsaade edilmesi için Moskova'daki Türkiye Büyükelçiliği’ne müracaat etmeleri neticesinde haberdar olduğu anlaşılmaktadır. ${ }^{72}$ Durumu öğrendikten sonra tepki göstermemiş olması dikkat çekicidir. Bu dönemde tepkisiz kalması; Sovyetler Birliği’nin malum gücü, Soğuk Savaş döneminin koşulları ve dayatmaları karşısında yeterli manevra alanının olmaması, sorunu gündeme getirerek çözüm talebinde bulunulmasının tamiri mümkün olmayan olumsuz sonuçlar doğurabileceği gibi gerekçelerle rasyonel hale getirilmek suretiyle açıklanabilir. Ancak Krasnodar Eyaleti'nde Rus yetkililerin Ahıska Türklerine yönelik baskısına sessiz kalınmasını anlamak mümkün değildir. Zaten bu dönemdeki tutumu, bazı Ahıskalılar tarafından ilgisizlik olarak yorumlanmıştır. ${ }^{73}$

Ahıska, Kafkasya'da Türk ve Rus çıkarlarının çakıştığı birçok alandan biridir. Bu kapsamda bölge, Rus çıkarları açısından olduğu kadar, Türk çıkarları açısından son derece önemlidir. Ahıska Türklerinin vatanlarına geri dönmesi halinde, Türkiye ile Türk Dünyası arasındaki kapalı olan kap1 yeniden açılabilecektir. Bu nedenle geri dönüş, Türkiye'ye büyük avantaj sağlamasının yanında, RF'nin bölgeyle ilgili malum niyetlerinin gerçekleşmesini de ciddi oranda engelleyebilecektir. Bu tip gerekçelerden bağımsız ve daha çok iyi komşuluk ilişkilerine zarar vermeme anlayışıyla hareket eden Türkiye, geri dönüşün Ahıska Türklerinin tarihi yerleşim

72 S. Enders Wimburs, ve Ronald Wixman, a.g.m. s.163.

73 Rüstem Mürseloğlu, “Hala Susmakta Kars, Erzurum, Ardahan!”, Ahıska Dergisi, 2004, 6, 4-5, s.5. 


\section{Mustafa ÜREN}

yerleri olan Ahıska'ya yapılması gerektiğine inanmaktadır. ${ }^{74}$ Zaten Ahıska dışındaki bir bölgeye yerleşilmesi halinde, geri dönüşün anlamını yitireceğini düşünmektedir. Gelişmeleri genellikle bu çerçevede takip eden Türkiye, sorunun Gürcistan ile ikili ilişkilerine zarar verme ihtimaline karşı ihtiyatlı davranmaktadır.

Küresel güç ABD'nin soruna yaklaşımında, jeopolitik ve küresel çıkarlarının etkili olduğu görülmektedir. Petrol ve doğalgaz boru hatlarının geçtiği güzergah üzerinde yer alan Ahıska'nın güvenliği, ABD açısından oldukça önemlidir. Bu bölgede etnik çatışmaların çıkmasıyla güvenliğin tehlikeye girmesi ve bunun neticesinde istikrarın bozulması olasılığ ABD'nin jeopolitik çıkarlarına aykırıdır. ${ }^{75} \mathrm{Bu}$ yüzden RF'nin Krasnodar Eyaleti'nde sorun yaşayan Ahıskalıları, istikrarsızlı̆ga neden olabilir endişesiyle çok yakınlarındaki vatanları Ahıska yerine binlerce kilometre

Üsküdar University Journal of Social Sciences Year:2 Issue:2 uzaklıktaki kendi ülkesine göç etmelerini sağlayarak pragmatist bir yaklaşım göstermiştir.

İran'ın soruna yönelik politikasının belirlenmesinde, milliyetçi refleks endişesinin etkili olacağ 1 düşünülmektedir. Geri dönüşle birlikte Ermenilerle Ahıska Türkleri arasında çıkabilecek bir çatışmanın yaratabileceği milliyetçi refleksin Güney Azerbaycan'a sıçramasından geçmiş dönemde olduğu gibi yine endişe duyması mümkündür. Nitekim Dağlık Karabağ çatışmaları döneminde yaşadığı endişe, Azerbaycan ile ilişkilerini derinden etkilemiştir. ${ }^{76} \mathrm{Bu}$ korelasyondan hareketle İran'ın Ahıska Türkleri Sorunu'nun çözümünde, tarafsız bir yaklaşım sergilese bile, genel olarak taraf olduğu ittifak grubunu destekleyen bir tutum sergileyeceği değerlendirilmektedir.

74 Yunus Zeyrek, "Dışişleri Bakanı Ahmet Davutoğlu: Ahıskalı Kardeşlerimizin Arkasındayız", Bizim Ahiska Dergisi, 2010, 20, 6-10, s.7.

75 A. Ali Aslan, "Ahıska Türklerinin Amerika'ya Göçü: Amerika'nın Uyguladığı Bir Sosyal Mühendislik Projesi”, Uluslararasl Ahıskalı Türklerin Hukuki ve Sosyal Sorunları Sempozyumu, 14-15 Nisan 2014, ed. R. Bayraktar, (Ankara: Astana Yayınları 2015), s.65.

76 Kamer Kasım, Soğuk Savaş Sonrası Kafkasya, 2. Baskı, (Ankara: USAK Yayınları 2011), s.146. 


\section{Çıkar ve Güç Dengesi Kıskacındaki Ahıska Türkleri Sorunu}

Bölgenin diğer aktörü Ermenistan, sözde doğal sınırlarına ulaşma gayreti içindedir. Gayretiyle uyumlu olmayan gücünü, RF ile ittifak kurmak suretiyle çoğaltma niyetindedir. Bunu yaparken neorealist paradigmanın bağımsızlığını kaybetme hususuyla ilgili yaptığı uyarılarını dikkate almadığını söyleyebiliriz. Bu konudaki eleştirilere kulak tıkamakta ve RF'nin sağladığ 1 güvenlik kalkanı vasıtasıyla bölgesel çıkarlarını gerçekleştirmeye çalışmaktadır. Dağlık Karabağ Sorunu'nu çıkarlarına uygun çözüme kavuşturmasının ardından tüm dikkatini, Ahılkelek'in de içinde yer aldığı Ahıska bölgesine çevirmesi kuvvetli bir olasılıktır. Dolayısıyla Ermenistan'ın Ahıska Türkleri Sorunu'na yönelik politikasını, esas olarak bu konuyla ilgili niyeti belirlemektedir.

Ermenistan, Ahıska'nın Ermeni jeopolitiğindeki önemi nedeniyle Ahıska Türklerinin buraya geri dönmelerine karşıdır. Bu tutumunda, üç etkenin rol oynadığını iddia etmek mümkündür. Bunların başında, Ahıska bölgesinin jeostratejik önemi gelmektedir. Ahıska; Ermenistan'1, deniz yolu vasıtasıyla dünyaya, kara yolu vasıtasıyla da RF'ye bağlamaktadır. Diğeri, Cavakheti bölgesinde yaşayan Ermenilerdir. Diasporadaki Ermenilerin de büyük desteğiyle Cavakheti Ermenilerinin, Ermenistan'ın Gürcistan ile ilişkilerini belirleyici bir unsur haline geldiği, sürekli dikkate alınması gereken bir husustur. ${ }^{77}$ Sonuncusu ise, Cavakheti bölgesinden göç ederek Ermenistan'a yerleşen 100.000'e yakın Ermeninin Ermenistan'ın iç politikasına etkisidir. ${ }^{78}$ II. Dünya Savaşı'ndan bu yana devam eden göçler neticesinde Cavakheti Ermenilerinin Ermenistan'ın hem iç, hem de dış politikasını etkileyebilecek bir potansiyele ulaştığını söylemek yanlış olmayacaktır. Dolayısıyla Ahıska'nın jeopolitik öneminin yanında, Cavakheti Ermenilerinin geri dönüşe karşı olması, Ermenistan'ın Ahıska Türklerine yönelik politikasını belirleyen faktörler olarak ön plana çıkmaktadır.

77 Hasan Kanbolat ve Nazmi Gül, "The Geopolitics and Quest for Autonomy of the Ermenians of Javakheti (Georgia) and Krasnodar (Russia) in the Caucasus", Ermeni Araştırmaları Dergisi, 2001, 2, 3-34, p.27.

78 Timuçin Kodaman ve A. Ali İren, “Gürcistan Ulus-İnşa Çabalarının Önünde Bir Engel: Cavaheti Ermenileri”, Uluslararası Alanya İşletme Fakültesi Dergisi, 2013, 5(2), 67-75, s.70. 


\section{Mustafa ÜREN}

Üsküdar University Journal of Social Sciences Year:2 Issue:2

Ahıska'nın Ermeni jeopolitiğindeki önemi nedeniyle Cavakheti Ermenileri, Türklerin buraya geri dönmesine şiddetle karşı çıkmaktadırlar. ${ }^{79}$ Kendilerini Gürcistan'dan ziyade Ermenistan'ın bir parçası olarak kabul eden Cavakheti Ermenilerinin Ruslarla tarihi bağlantısı, onları sorunla ilgili yapılacak değerlendirmelerde dikkate alınması gereken önemli bir aktör haline getirmektedir. "Büyük Ermenistan" hayaliyle yaşayan ve daha önce Türk düşmanlığıyla doktrine edilmiş olan Cavakheti Ermenilerinin, Rus desteğini arkalarında hissettiği müddetçe, Ahıska Türklerinin bölgeye geri dönmemeleri için her firsattan yararlanacaklarını göz önünde bulundurmak yararlı olacaktır.

Güney Kafkasya'nın önemli devletlerinden biri olan Azerbaycan ise, sorunun ortaya çıktığı andan itibaren Ahıskalılara daima ilgi göstermiş ve imkanları ölçüsünde desteklemeye çalışmıştır. Sorunun çözümüyle ilgili tüm girişimleri, bugüne kadar olduğu gibi bundan sonra da desteklemeye devam edeceği düşünülmektedir.

Netice itibariyle, gerek Kafkasya'daki siyasi ortamın soruna etkisine, gerekse bu ortamdaki aktörlerin soruna yönelik genel tutumlarına bakıldığında, Ahıska Türklerinin vatanlarına geri dönüşte başarılı olamamalarının nedenleri daha iyi anlaşılmaktadır. Sürgünle başlayan sürece, her geçen gün yeni engelleyici faktörler dahil olmuş ve Ahıska'ya geri dönme, örgütlenme sorunları yaşayan bir toplumun yetenekleri dışına çıkmıştır. Bu kapsamda öncelikle Sovyet Yönetimi'ne karşı başlattıkları hak mücadelesi, onun dağılmasıyla Gürcistan'a karşı tek başlarına yürütülmek zorunda kalınan “asimetrik güç mücadelesi” ne dönüşmüştür. Asimetrik mücadele, Ahıskalıların zaten aleyhlerine olan koşulları daha da ağırlaştırmıştır. Örneğin Sovyetler Birliği’nin dağılmasıyla Ahıskalılar, bir anda altı farklı ülkede yaşamak zorunda kalmışlardır. Günümüzde 10 farklı ülkede ve üstelik 4.300'e yakın farklı yerleşim biriminde dağınık bir şekilde yaşamaktadırlar. ${ }^{80}$ Örgütlenme, dayanışma ve işbirliği alanlarında

79 Oskari Pentikainen and Tom Trier, a.g.e., p.18.

80 Orhan Uravelli, “Ahıska Türkleri Sorunu ve Gürcü Meskh Tezi”, XII. Türk Tarih Kongresi Bildirileri Içinde, II. Cilt, (Ankara: Türk Tarih Kurumu Basımevi 1999), 361-363, s.361. 


\section{Çıkar ve Güç Dengesi Kıskacındaki Ahıska Türkleri Sorunu}

ciddi sorunları bulunmaktadır. Ortak mücadele için bir araya gelerek güç oluşturma yerine, iç ve dış faktörlerin etkisiyle kendi aralarında bölünme giderek artmaktadır. Çoğunlukla kırsal kesimde yaşamalarından dolay1 eğitim seviyeleri düşüktür. $\mathrm{Bu}$ nedenle geri dönüş davasını jeostratejik ve jeopolitik esaslara göre değerlendirip bunun bölgesel etkilerini ortaya koyabilecek ve geri dönüşe rehberlik yapabilecek elit gruplardan yoksundurlar. Buna karşılık geri dönüşlerine karş1 çıkan RF, bölgedeki oyunun kurallarını belirleyen bir güç; Gürcistan, bölgenin en zayıfı da olsa bir devlet; Ermeniler ise, siyasi bakımdan örgütlü bir toplumdur. Yine eğitim seviyelerinin düşük olmasına bağlı olarak Ahıskalıların geri dönüşü uluslararası hukuk açısından değerlendirip, bunun neticesinde ortaya çıkacak hak ve yükümlülüklere göre hareket etme kapasiteleri bulunmamaktadır. Böyle bir değerlendirme yapılmadan uluslararası ortamda hak arama mücadelesinin istenen sonuçlara ulaşması, mümkün olsa bile oldukça zordur. Ayrıca Gürcistan'ın geri dönüş yasası kapsamındaki sorumluluklarını yerine getirmemesi halinde, Ahıskalıların onun üzerinde baskı oluşturma imkanları yok denecek kadar azdır. Bunun sebebi, büyük oranda Ahıskalıların tamamına yakınının Gürcistan dışında yaşamasından kaynaklanmaktadır. Uluslararası kurum ve kuruluşlarda temsilcileri olmaması nedeniyle, dolaylı baskı kurma mekanizmasına da sahip değildirler. Aslında tanımlanması yapılan mevcut ortam, taraflar arasındaki asimetrik durumu gayet somut ve açık bir biçimde ortaya koymaktadır.

$\mathrm{Bu}$ asimetrik dezavantajın yanında bir de Türkiye'nin sorunu ittifak ilişkilerine yansıtmama yönündeki eğilimi, Ahıska Türklerinin durumunu daha da zorlaştırmaktadır. Böyle bir durumda Ahıska Türklerinin, uluslararası sistemin temel aktörlerinden biri olan Gürcistan ile mücadele etmesinin mevcut yetenekleriyle uyumlu olmadığ1 ve hatta mümkün olmadığ1 sonucu ortaya çıkmaktadır. Söz konusu handikap1 aşabilmenin yegane koşulu, uluslararası sistemin bu tip sorunların çözümü için sunduğu mekanizmaları harekete geçirebilmek için güçlü bir devlet desteğine sahip olmaktır. Bunu yapabilecek devlet, doğal olarak Türkiye'den başkası değildir. Zaten Türkiye de sorunun taraflarından biridir. Bu nedenle 


\section{Mustafa ÜREN}

sorunun Ahıskalıların lehine çözümü için Türkiye'nin mevcut tutumunu değiştirmesinin dışında başka bir seçenek kalmamaktadır.

\section{Sonuç}

Rus çıkarları gereği Sovyet Yönetimi döneminde vatanlarından sürgün edilen Ahıska Türkleri, tüm çabalarına karşın Ahıska'ya geri dönüş konusunda muvaffak olamamışladır. 1956 yılında başlattıkları geri dönüş mücadelesinde, egemen güç Sovyetler Birliği'nin yasalarına her zaman bağlı kalmışlar ve şartlar giderek ağırlaşmasına rağmen hiçbir zaman hukuk dışı yönteme başvurmamışlardır. Günümüze kadar hukuki sınırlar içinde verdikleri mücadeleden arzu ettikleri sonucu elde edemedikleri ortadadır.

Üsküdar University Journal of Social Sciences Year:2 Issue:2

Sorunun çözümünü zorlaştırılan temel faktör, RF ve Gürcistan'in bu konudaki çıkar uyumudur. İki aktör de, çıkarları gereği Ahıska Türklerinin geri dönüşüne karşıdır. Gürcistan, sadakatinden her zaman endişe duyduğu Ermenistan ile sınır hattındaki Ermenilerin yanında, bir de Türkiye sınırında Türklerin oluşturacağı yeni bir azınlık grup istememektedir. RF'nin geri dönüşe karşı çıkma sebebi ise, buradaki Ermeniler vasıtasıyla sahip olduğu avantajlı konumunu kaybetme ihtimalidir. Geçmişte Kafkasya'yı Rus çıkarlarına uygun şekillendirme politikasını miras olarak devralan RF'nin jeostratejik açıdan oldukça önemli bir yerde bulunan Ahıska bölgesinden vazgeçmesi mümkün değildir. 1990'lı yılların ortasında Gürcistan ile imzaladığ antlaşma gereği bir askeri üssünü bu bölgeye yerleştirmesi bunu ispat etmektedir. Yine Edirne Antlaşması ve I. Dünya Savaşı'ndan sonra Anadolu'dan gelen Ermenileri bu bölgeye yerleştirmesi de yine aynı gerekçeyle izah edilebilir. Daha önceki uygulamaları dikkate alındığında çıkarları gereği RF'nin, Ahıska'nın gelecekte Ermeni coğrafyasına dahilolma beklentisiyle, bölgede Ermenilerin lehine olan etnik yapının değişmesine müsaade etmeyeceği düşünülmektedir. Ahıska Türklerinin vatanlarına geri dönmesi, RF açısından bölgenin Gürcistan'ın egemenliğinde kalmasının pekiştirilmesi anlamına gelmektedir. Diğer bir deyişle, Ahıska'nın gelecekte 


\section{Çıkar ve Güç Dengesi Kıskacındaki Ahıska Türkleri Sorunu}

Ermeni coğrafyasına dahil olma olasılı̆̆ının tamamen ortadan kalkması demektir. Bu yüzden eski sahiplerinin vatanlarına geri dönmesi RF'nin çıkarlarına aykırıdır. Bölgenin Rus çıkarları bakımından önemi dikkate alındığında, Gürcistan Ahıskalıların geri dönüşünü onaylasa bile, RF'nin bunu engelleyebilmek için elindeki tüm imkanları sırasıyla kullanmasının daha rasyonel bir hareket tarzı olduğu söylenebilir.

Ermeni kartını her an kullanma gibi bir avantaja sahip olan RF'nin Ahıska Türklerinin geri dönüşüne karşı olumsuz yaklaşımını anlamak mümkündür. Ancak Gürcistan için durum tamamen farklıdır. Gürcistan'ın Ahıska'ya geri dönüşe izin vermeme yönündeki ısrarı, bölgeyle ilgili uzun vadeli çıkarlarına zarar vermektedir. Bölgedeki mevcut koşullar gereği, tarihi Rus-Ermeni dostluğunun Ahıska'da komploya dönüşmesinden endişe duymaktadır. RF'nin Ağustos 2008 müdahalesiyle ilgili yabanc1 uzmanların yorumlarında, RF'nin Cavakheti'deki Ermenilerin merkezi yönetime karşı bir baskı vasıtası olarak kullanılabileceği hususu sık sık gündeme getirilmiştir. RF'nin o dönemde beklentilerin aksine Ermeni kartını kullanmamış olması, Gürcistan açısından rehavete kapılma yerine kalıcı çözüm bulma konusunda itici bir güç olması daha rasyonel bir hareket tarzıdır. Ahıska Türklerinin geri dönüşü, Gürcistan aksini iddia etse de, kalıcı çözüm için kendisine oldukça uygun bir firsat sunmaktadır. Geri dönen Ahıskalılar vasıtasıyla, söz konusu Ermeni tehdidi dengelenebileceği gibi, RF'nin bölgeyi şekillendirme konusuyla ilgili malum niyetinin de boşa çıkarılması mümkün olabilecektir. Benzer şartlarda Ahıska Türklerinin ataları Kıpçaklarla Gürcü Krallığı, 12. yüzyılda bu işbirliğini başarmışlardır. Günümüzde tekrar başarılmaması için görünürde hiçbir neden yoktur.

İnceleme neticesinde elde edilen verilere göre, Gürcistan ve RF'nin çıkarlarının uyuşmasından dolayı Ahıska Türkleri Sorunu'nun kısa ve orta vadede çözümünün mümkün olsa bile kolay olmadığı ortaya çıkmaktadır. Bölge istikrarını etkileme potansiyelinden dolayı güç dengesi de, sorunun çözümünü olumsuz yönde etkilemektedir. Bu olumsuz atmosfere karş1l1k, Gürcistan'ın bağımsızlığıyla birlikte siyasal tercihini Batı Dünyası'ndan 


\section{Mustafa ÜREN}

yana kullanması ve Kafkasya'daki güç dengesinde RF yerine ABD'nin lideri olduğu ittifak grubu içinde yer alması, sorunun uzun vadeli çözümü konusunda elverişli bir ortam yaratmaktadır. Ortamı elverişli kılan faktörlerin başında ise, şüphesiz Gürcistan'ın Avrupa Konseyi’ne üye olmas1 gelmektedir.

Soruna bu çerçeveden bakıldığında, Ahıska Türklerinin önlerine çıkan bu elverişli ortamdan tam olarak istifade edemedikleri görülmektedir. Aslında Avrupa Konseyi, Ahıska Türklerinin önünde iki önemli firsat sunmuştur. Bunlardan ilki, uluslararası hukukun etkin olarak kullanılmasıdır. Ahıskalıların uluslararası hukuku etkin bir mücadele vasıtası olarak kullanmayı başarmaları halinde, Gürcistan ile aralarındaki asimetrik konumun yarattığı sıkıntılardan büyük oranda kurtulma şansını yakalayabileceklerdir. $\mathrm{Bu}$ konuda, geri dönüşe uzun y1llar direnen

Üsküdar University Journal of Social Sciences Year:2 Issue:2 Gürcistan'ın Avrupa Konseyi'ne üye olma adına Avrupa İnsan Hakları Sözleşmesi (AİHS) gereği geri dönüş yasasını kabul etmek zorunda kalması, cesaret verici bir başlangıç kabul edilebilir.

Diğeri ise, uluslararası sistemde tesis edilmiş olan insan hakları rejimlerinden kuruluş felsefelerine uygun şekilde yararlanılması hususudur. AİHS çerçevesinde Avrupa'da oluşturulan insan hakları sistemi, Ahıskalılar lehine uygun ve eşit mücadele koşulları yaratmaktadır. Geri dönüş yasasının AİHS gereği kabul edilmiş olmasından sorunun uluslararası alanda "insan hakları sorunu" olarak kabul edildiği sonucu çıkarılabilir. Geri dönüş yasası, AHİS gereği çıkarıldıysa, onun yarattığı sistemden istifade ederek sürecin aktif hale getirilmesi ve tıkanıklarının aşılması da mümkün olabilecektir. Bunun için sistem içinde özellikle Avrupa Halkları Federal Birliği (AHFB) ve Avrupa Azınlık Sorunları Merkezi (AASM) gibi kurum ve kuruluşların işlevlerinin iyi bilinmesine ihtiyaç vardır. Zira adı geçen iki kurum ve kuruluş, Avrupa kamuoyunun oluşturulmasında çok önemli role sahip olmasının yanında, özellikle AHFB; AB, Avrupa Konseyi ve AGİT gibi Avrupalı örgütlerin karar alma süreçlerinde etkin lobi faaliyeti yürütmektedir. Dolayısıyla adı geçen kurum ve kuruluşların 


\section{Çıkar ve Güç Dengesi Kıskacındaki Ahıska Türkleri Sorunu}

imkanlarından yararlanmak suretiyle AB, Avrupa Konseyi ve AGİT nezdindeki girişimlerden daha rahat sonuç alınarak Gürcistan üzerinde arzu edilen baskı oluşturulabilecektir.

\section{KAYNAKCุA}

A. Ali Aslan, "Ahıska Türklerinin Amerika'ya Göçü: Amerika'nın Uyguladığı Bir Sosyal Mühendislik Projesi”, Uluslararası Ahıskalı Türklerin Hukuki ve Sosyal Sorunlarl Sempozyumu, 14-15 Nisan 2014, ed. R. Bayraktar, (Ankara: Astana Yayınları 2015).

A. Bican Ercilasun, "Meshet-Ahıska Türkleri Hakkında", Türkeli Dergisi, 2005, 116.

A. Muhtar Ataç, Rusya Tarihi: Türkler ve Komşularıla Münasebetleri, (Ankara: Genelkurmay 1 No.11 Basımevi 1952).

A. Tacıbayeva, "68 Yıldır 10 Ayrı Ülkede Vatan Hasreti Çekiyoruz", Ipekyolu Gezi ve Kültür Dergisi, 2013, 16, 38-45.

A. Zeki Velidi Togan, Umumi Türk Tarihine Giriş, I. Cilt, 3. Baskı, (İstanbul: Enderun Kitabevi 1981).

Alexander Osipov, Russian Experience of Ethnic Discrimination: Meskhetians in Krasnodar Region, (Moscow/RF: The Report Published By Memorial Human Rights Center 2000).

Andrei Khanzhin, "Durable Solutions for Meskhetian Turks: The issue revisited”, European Yearbook of Minority Issues, 2004, 4(5), 495-511.

Andrew Heywood, Global Politics, (New York/USA: Broadcasting of Palgrave Macmillan 2011). 


\section{Mustafa ÜREN}

Arif Yunusov, Meskhetian Turks: Twice Deported People, (Baku: The Research Document Published by The Institute of Peace and Democracy 2000).

Atila Eralp, "Sistem". Devlet ve Ötesi İçinde (9. Baskl), (Ankara: İletişim Yayınları 2012), 125-153.

Aygün Attar, "Zangezur İli Nasıl Ermenilerin Oldu?", Askeri Tarih Araştırmaları Dergisi, 2003, 2, 1-10.

Ayşegül Aydıngün, “Ahıska Türklerinin Dünü, Bugünü ve Yarını”, Yeni Türkiye Dergisi Türk Dünyası Özel Saylsı II, 2013, 54, 2665-2674.

Üsküdar University Journal of Social Sciences

Year:2

Issue:2

, Ahıska Türklerinin Gürcistan'a Dönüşü, (Ankara: ASAM Yayını No: 6 2008).

--------------, “Ahıska (Meskhetian) Turks: Source of Confilict in the Caucasus". International Journal of Human Rigths, 2002, 6 (2), 49-64. "Rethinking on Ethnic Identity Formation and Shift: The Case of the Ahiska (Meskhetian) Turks", The Faculty of the Department of Sociology of Middle East Technical University, Unpublished Doctor's Thesis, Ankara 2001.

Ayşegül Aydıngün vd, Meskhetian Turks, Culture Profile No: 20, (Washington/USA: Publication of The Center for Applied Linguistics 2006).

Beşir Mustafayev, "Cihan Hakimiyetini Moskoflara Öğütleyen Deli Petro'nun Vasiyetnamesi ve Ermenistan Devletinin Kurulmasında Etkisi”, Uluslararası Avrasya Sosyal Bilimler Dergisi, 2013, 11, 17-27, s.22.

C. Jin Oh, "Comparative Analysis of The Ahiska (Meskhetian) Turks and Koreans in Post-Soviet Kazakhstan and Uzbekistan: The Making of Diaspora Identity and Culture”, Millî Folklor Uluslararası Kültür Araştırmaları Dergisi, 2012, 94, 14-26. 


\section{Çıkar ve Güç Dengesi Kıskacındaki Ahıska Türkleri Sorunu}

Charles Blandy, The Meskhetians: Turks Or Georgian? A People without A Homeland, (Surrey/England: Publication of Conflict Research Center 1998).

Dünya Ahıska Türkleri Birliği, DATÜB 2010-2014 Faaliyetleri, (Ankara: DATÜB Yayını 2014).

Ergin Güneş, "Tehdit Algılamaları Ekseninde Rusya'nın Yakın Dönem Kafkasya ve Orta Asya Politikası", Akdeniz İ.I.B.F. Dergisi, 2013, 27, 176-203.

Geoffrey Gresh, "Coddling The Caucasus: Iran's Strategic Relationship with Azerbaijan and Armenia", Caucasian Review of International Affairs, 2006, 1(1), 1-13.

H. Basri Yalçın, "Uluslararası Sistem ve İstikrar: Kavramsal Bir Değerlendirme”, Akademik Incelemeler Dergisi, 2015, 10(1), 209-229.

Hasan Kanbolat ve Nazmi Gül, "The Geopolitics and Quest for Autonomy of the Ermenians of Javakheti (Georgia) and Krasnodar (Russia) in the Caucasus", Ermeni Araştırmaları Dergisi, 2001, 2, 3-34.

Hasan Oktay, "Kafkaslarda Barışın Önündeki Engeller ve Ermenistan”, 21. Yüzyılda Türk Dünyası Uluslararası Sempozyumu Bildirileri, 02-05 Aralık 2010, (Lefke: EkoAvrasya Yayınları 2011), 317-320.

Hayati Aktaş ve Seyfettin Buntürk, "Güney Kafkasya'da Güç Mücadelesi ve Ahıska Türklerinin ABD'ye Göçü’, Türk Dünyası Araştırmaları Dergisi, 2007, 167, 129-142.

Hedvig Lohm, Javakhaeti After the Rose Revolution: Progress and Regress in the Pursuit of National Unity in Georgia, Working Paper No: 38, (Flensberg/Germany: Publication of ECMI 2007).

International Crisis Group(ICG), Georgia: The Javakheti Region's Integration Challenges, (Brussels/Belgium: Europe Briefing No: 63 2011). 


\section{Mustafa ÜREN}

Isabelle Kreindler, "Soviet Deported Nationalities: A Summary and An Update”, Soviet Studies, 1986, 38 (3), 387-405.

John J. Mearsheimer, "Back to The Future: Instability in Europe After The Cold War", International Security, 1990, 25(1), 5-56.

John J. Mearsheimer, "Structural Realism". International Relations Theories: Discipline and Diversity Within, eds. T. Dunne, M. Kurki and S. Smith. (Oxford/England: Oxford University Pres 2007). 71-88.

Jonathan Wheatley, The Integration of National Minorities in the SamtskheJavakheti and Kvemo Kartli Provinces of Georgia, Working Paper No: 44, (Flensberg/Germany: Publication of ECMI 2009).

Üsküdar University Journal of Social Sciences Year:2 Issue:2

Obstacles Impending the Regional Integration of the Javakheti Region of Georgia, Working Paper No: 22, (Flensberg/Germany: Publication of ECMI 2004).

Justin McCarthy, Ölüm ve Sürgün: Osmanlı Müslümanlarının Etnik Kıyımı (1821 - 1922), Çev. F. Sarıkaya, (Ankara: TTK Yayınları 2012).

Kamer Kasım, Soğuk Savaş Sonrası Kafkasya, 2. Baskı, (Ankara: USAK Yayınları 2011).

Kemal Özcan, "II. Dünya Savaşı Sirasında Sovyetler Birliği'nde Yaşanan Sürgün Hadiseleri”, Türk Dünyası Araştırmaları Dergisi, 2002, 141, 135-138.

Kenneth N. Waltz, "Realist Thought and Neorealist Theory", The Journal of International Affairs, 1990, 44(1), 21-37.

--------------, “Uluslararası İlişkiler Kuramı”. Uluslararası İlişkiler Kuramı ve Dünya Siyasal Sistemi Iç̧inde, Çev. E. Onulduran, (Ankara: Ankara Üniversitesi Siyasal Bilgiler Fakültesi Yayınları No: 510 1982), 3-95. 
Çıkar ve Güç Dengesi Kıskacındaki Ahıska Türkleri Sorunu

, Theory of International Politics, (California/USA: Addison-Wesley Publishing Company 1979).

M. Fahrettin Kırzıoğlu, "Hristiyan Atabekler Hükümeti-I", Bizim Ahıska Dergisi, 2008, 10, 12-17.

--------------, Osmanlılar'ın Kafkas-Elleri'ni Fethi, 2. Bask1, (Ankara: Türk Tarih Kurumu Basımevi 1998).

Basımevi 1992).

, Yukarı Kür ve Çoruk Boyları'nda Kıpçaklar, (Ankara: TTK “Ahıska Bölgesi ve Türklük”, Türk Kültürü Dergisi, 1969, 86, 203-206. , 1855 Kars Zaferi, (İstanbul: Iş11 Matbaası 1955).

Muhsin Yazıcıŏlu, “Ahıska Türkleri Meselesi Milli Bir Davadır”, Bizim Ahiska Dergisi, 2007, 7, 11-12.

Nana Sumbadze, "Back Home Again: The Repatriation and Integration of Meskhetian Muslims in Georgia", The Meskhetian Turks at a Crossroads: Integration, Repatriation or Resettlement Within, eds. T. Trier and A. Khanzhin, (Berlin/Germany: Publication of ECMI 2007), 288-377.

Nazim Cafersoy, "Rus Jeopolitik Düşüncesinde Misyon Arayışları", Avrasya Uluslararası İlişkiler ve Stratejik Araştırmalar Dergisi, 2002, 4 (8), 51-101.

Okan Yeşilot, "Türkmençay Antlaşması ve Sonuçları", Türkiyat Araştırmaları Enstitüsü Dergisi, 2008, 36, 187-199.

Oleg Kuznetsov, "Constructing Identity and Social Networks: Meskhetian Turks in Russian Federation", The Meskhetian Turks at a Crossroads: 


\section{Mustafa ÜREN}

Integration, Repatriation or Resettlement Within, eds. T. Trier and A. Khanzhin, (Berlin/Germany: Publication of ECMI 2007), 197-237.

Orhan Uravelli, "Razdan Madoyan'1 Okurken”, Bizim Ahıska Dergisi, 2006, 6, 21-22.

, “Ahıska Türkleri Sorunu ve Gürcü Meskh Tezi”, XII. Türk Tarih Kongresi Bildirileri İ̧̧inde, II. Cilt, (Ankara: Türk Tarih Kurumu Basımevi 1999), 361-363.

Oskari Pentikainen and Tom Trier, Between Integration and Resettlement: The Meskhetian Turks, Working Paper No: 21, (Flensberg/Germany: Publication of ECMI 2004).

Rasim Bayraktar, "Ahıska Türklerinin Dünyadaki Nüfus Dağılımı”, 2023

Üsküdar University Journal of Social Sciences Year:2 Issue:2

Dergisi, 2013, 148, 72-77.

Roin Kavrelişvili, “Güney Gürcistan'dan Sürgüne Gönderilen Toplulukların Geriye Dönüş Yolundaki Hukuki Durumu”, Uluslararası Ahiskalı Türklerin Hukuki ve Sosyal Sorunları Sempozyumu, 14-15 Nisan 2014, ed. R. Bayraktar, (Ankara: Astana Yayınları 2015).

Rüstem Mürseloğlu, "Hala Susmakta Kars, Erzurum, Ardahan!", Ahiska Dergisi, 2004, 6, 4-5.

S. Enders Wimburs ve Ronald Wixman, "Sovyet Orta Asyası'nda Yeni Bir Seda: Mesketya Türkleri”, Çev. E. Özbilen, Türk Dünyası Araştırmaları Dergisi, Ağustos 1987, 151-170.

Sascha Kuhn vd, Energy Cooperation in the Caucasus: Continuity and Change in Russian-Turkish Relations, (Malmö/Sweden: A Report Published by Malmö University 2010).

Seyfettin Buntürk, Rus Türk Mücadelesinde Ahiska Türkleri, (Ankara: Berikan Yayınevi 2007). 


\section{Çıkar ve Güç Dengesi Kıskacındaki Ahıska Türkleri Sorunu}

Stefanos Yerasimos, Milliyetler ve Sinırlar, 6. Bask1, (İstanbul: İletişim Yayınları 2010).

Şamil Kurbanov, “Ahıska Türkleri”, Azerbaycan Türk Kültür Dergisi, 1991, 279, 11-16.

Şerafettin Turan, “1829 Edirne Antlaşması”, Ankara Üniversitesi Dil ve Tarih Coğrafya Fakültesi Dergisi, 1951, 1-2 (IX), 111-151.

Thomas Diez vd, Key Concepts in International Relations, (London/UK: SAGE Publications 2011).

Timuçin Kodaman ve A. Ali İren, "Gürcistan Ulus-İnşa Çabalarının Önünde Bir Engel: Cavaheti Ermenileri”, Uluslararası Alanya Işsletme Fakültesi Dergisi, 2013, 5(2), 67-75.

Tom Trier vd, Meskhetians: Homeward Bound, (Tbilisi/Georgia: Publication of ECMI 2011).

Y. Hikmet Bayur, Türk Inkılap Tarihi: 1914-18 Genel Savaşı/Savaşı Sonu, III. Cilt, Kısım: 4, 2. Baskı, (Ankara: Türk Tarih Kurumu Basımevi 1991).

Yunus Zeyrek, "Dışişleri BakanıAhmetDavutoğlu:AhıskalıKardeşlerimizin Arkasındayız", Bizim Ahiska Dergisi, 2010, 20, 6-10. 